\title{
Dental Trauma First-Aid Knowledge and Attitudes of Physical Education Teachers: A Systematic Review and Meta-Analysis of the Literature with Meta-Regressions
}

\author{
Khaled Trabelsi $^{1}$ (D), Roy Jesse Shephard ${ }^{2}$, Sahar Zlitni ${ }^{1}$, Omar Boukhris ${ }^{1}$, Achraf Ammar ${ }^{1,3}$ (D), $^{1}$

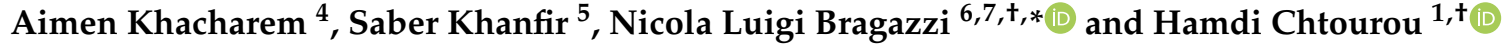 \\ 1 UR15JS01: Education, Motricité, Sport et Santé (EM2S), High Institute of Sport and Physical Education, \\ University of Sfax, Sfax 3000, Tunisia; trabelsikhaled@gmail.com (K.T.); sahar.zlitni@gmail.com (S.Z.); \\ omarboukhris24@yahoo.com (O.B.); ammar1.achraf@ovgu.de (A.A.); h_chtourou@yahoo.fr (H.C.) \\ 2 Faculty of Kinesiology and Physical Education, University of Toronto, Toronto, ON M5S 1A1, Canada; \\ royjshep@shaw.ca \\ 3 Institute of Sport Sciences, Otto-von-Guericke University, 39104 Magdeburg, Germany \\ 4 Department of Sport Sciences, Laboratoire Interdisciplinaire de Recherche sur les Transformations des \\ Pratiques Educatives et des pratiques Sociales (LIRTES - EA 7313), Université \\ Paris-Est-Créteil-Val-de-Marne (Parix-XII), 9400 Créteil, France; aimen.khacharem@u-pec.fr \\ 5 Faculty of Medicine, University of Tunis El Manar, Tunis 1003, Tunisia; khanfir.saber88@gmail.com \\ 6 Department of Health Sciences (DISSAL), Postgraduate School of Public Health, University of Genoa, \\ 16132 Genoa, Italy \\ 7 Department of Mathematics and Statistics, Laboratory for Industrial and Applied Mathematics (LIAM), \\ York University, Toronto, ON M3J 1P3, Canada \\ * Correspondence: bragazzi@yorku.ca \\ + These authors share equal last contribution.
}

Received: 8 May 2019; Accepted: 15 August 2019; Published: 3 October 2019

\begin{abstract}
The main objective of the present review is to evaluate the knowledge and attitudes of physical education (PE) teachers concerning dental trauma first-aid through a systematic appraisal of the literature, meta-analysis and meta-regressions. The entire content of PubMed and ISI/Web of Science was mined. Eligibility criteria for selecting studies were studies evaluating dental trauma first-aid knowledge and/or attitudes and/or the effectiveness of mouthguards use by PE teachers. Articles written in any language and published or accepted by peer-reviewed journals were considered. Methodological quality was assessed using an adapted version of the Downs and Black instrument. Of 15 selected articles, three were of strong quality, three were moderate, and the remaining nine were rated as weak. The majority of studies showed that PE teachers had an inadequate knowledge of the initial management of dental trauma. Specifically, there was a lack of knowledge concerning an appropriate washing and transporting medium and the extra-alveolar period of an avulsed tooth. Due to the inadequate knowledge of PE teachers regarding dental trauma management, specific education should be added to PE classes to improve the emergency treatment of dental injuries.
\end{abstract}

Keywords: physical education teachers; dental injuries; education; knowledge; attitudes; systematic review and meta-analysis; meta-regressions 


\section{Introduction}

Regular physical activity has many benefits for school-aged children and youth in terms of growth, health, and psychosocial outcomes, such as self-esteem and cognitive functioning [1-4]. However, sport participation may also lead to dental trauma [5], including tooth avulsion (displaced and lost teeth), tooth fracture (broken teeth), facial and temporo-mandibular fractures, and soft tissue injuries [6].

In the last few decades, an increased risk for dental trauma in some sports disciplines such as basketball and football has been reported, especially among intercollegiate athletes, possibly due to a lesser use of mouthguards. Other sports characterized by a high risk for dental injuries include rugby and water sports. Dental trauma may also occur at home or at school [7-11], particularly during physical education (PE) classes and sports club activities [6].

The loss of an avulsed tooth has both functional (e.g., phonetics, mastication, integrity of supporting tissues) and psychological (e.g., mental and emotional wellbeing) consequences [12,13]. Berger et al. [12] observed an immediate decrease in quality of life for both the affected child and the parents, with the disturbance of the child's social and emotional wellbeing persisting as long as one year after the initial trauma. Appropriate first-aid management can minimize these negative psycho-social consequences, as well as pain, tooth loss, prolonged treatment, and high associated costs [14].

A prompt and correct emergency management is especially important following tooth avulsion $[15,16]$. The success of reimplantation depends on the appropriate storage of the tooth, the extra-alveolar period, the type of retention employed, the interval to endodontic intervention, the drugs prescribed, and levels of oral hygiene and general health [17]. Appropriate procedures are well-known and have been described extensively in many review articles [6,18-22] as well as books $[16,23,24]$.

Briefly, after washing the injured area (not aggressively) with sterile water and dabbing with gauze, an avulsed permanent tooth must be either reinserted by the crown into its original location in the mouth immediately, or stored in a suitable medium (e.g., Viaspan, Hank's balanced salt solution, milk, or saliva) $[16,18,19,21-23]$. Once replanted, the tooth may be splinted using a simple tissue adhesive (for instance, cyanoacrylate derivatives) before visiting a specialist for fixation and administration of antibiotics [19]. In the case of a displaced tooth, the latter should be appropriately repositioned using only finger pressure. If the displaced tooth shows an exposed pulp, the latter should be covered with a calcium hydroxide resin. If a tooth is broken, segments must be found and preserved in a suitable medium (as previously mentioned) to allow a specialist to reattach the fragments [25]. Appropriate emergency management should also include the parents and/or teachers who are available at the site of accident [13].

Teachers of PE should thus be capable of managing such injuries [26]. The only existing literature review on this issue is narrative in type and needs updating [20]. Thus, a systematic review and meta-analysis with meta-regressions was conducted concerning the first-aid dental trauma knowledge and attitudes among teachers of PE, with a view to developing evidence-based decisions on the best actions to take in order to increase the knowledge of PE teachers on this important issue.

\section{Materials and Methods}

\subsection{Systematic Review and Meta-Analysis Protocol}

The reporting of the present systematic review and meta-analysis with meta-regressions followed the "Preferred Reporting Items for Systematic Reviews and Meta-Analysis (PRISMA)" guidelines [27].

An a priori protocol was devised and can be requested from the corresponding author. Meta-analysis and meta-regression were added a posteriori. 


\subsection{Eligibility Criteria}

Articles written in any language and published or accepted for publication in peer-reviewed journals that evaluated the level of knowledge and/or attitudes of PE teachers relative to mouthguards use and dental first-aid measures were considered. No restrictions were applied in terms of study design, setting, country, or time frame.

Descriptive or review articles, conference proceedings, abstracts and articles based on teachers of other disciplines, coaches, athletes, and parents were excluded. Included studies were required to use an instrument (not necessarily validated) stating the proportion of participants who answered questions correctly.

The choice to also include reports based on non-validated tools was made in order:

(i) to provide readers with a more comprehensive review of the topic,

(ii) to verify the potential impact of validation on the outcomes of interest (through meta-analytical techniques and meta-regression analyses), and

(iii) to identify new research avenues, capitalizing on the lessons learned and overcoming shortcomings in previous research.

\subsection{Information Sources and Search}

International scholarly databases (PubMed and ISI/Web of Science) were searched from inception through to 20 November 2018, without time limits or filters, using the following terms (see Table 1): "dental trauma", "dental injury", "tooth avulsion", "tooth fracture", "mouthguards", first-aid, knowledge, attitudes, practices, "teachers of physical education", and "physical education teachers". Appropriate Boolean connectors were utilized to connect the various keywords and wild-card options (i.e., truncated words) and medical subject headings (MeSH) terms were also used where appropriate.

One author (K.T.) hand-searched the reference lists of included articles, as well as other citations identified via Google Scholar and a search of personal files, thus performing extensive cross-referencing. Specialists in the field were also contacted for information on upcoming studies, and specific target journals (such as "Dental Traumatology", "Pediatric Dentistry", "International Journal of Clinical Pediatric Dentistry", "The British Dental Journal", "Journal of Oral Health and Biosciences") were hand-searched for relevant studies. Further information on the search process is presented in Table 1.

Table 1. A summary of the search strategy adopted in the present systematic review and meta-analysis with meta-regressions assessing first-aid dental trauma knowledge and attitudes in physical education teachers.

\begin{tabular}{|c|c|}
\hline Search Strategy Item & Search Strategy Details \\
\hline String of keywords & $\begin{array}{l}\text { ((dental OR "dental trauma" OR "dental injury" OR "dental accident" OR "tooth } \\
\text { avulsion" OR "avulsed tooth" OR "tooth displacement" OR "displaced tooth" } \\
\text { OR "tooth fracture" OR "fractured tooth" OR "broken tooth" OR "tooth breaking" } \\
\text { OR "tooth breakage" OR "tooth break" OR "tooth crack" OR "tooth cracking" OR } \\
\text { "cracked tooth" OR "tooth loss" OR "lost tooth" OR "dental avulsion" OR "dental } \\
\text { displacement" OR "dental facture" OR "dental breakage" OR "dental breaking" } \\
\text { OR "dental break" OR "dental crack" OR "dental cracking" OR "dental loss" OR } \\
\text { mouthguards) AND first-aid AND (knowledge OR attitudes OR practices)) AND } \\
\text { ("teachers of physical education" OR "physical education teachers") }\end{array}$ \\
\hline $\begin{array}{l}\text { Searched databases/ } \\
\text { bibliographic thesauri }\end{array}$ & PubMed, ISI/Web of Science \\
\hline Inclusion criteria & $\begin{array}{l}\text { P (population): Physical education teachers } \\
\text { I (intervention/exposure): None } \\
\text { C (comparators/comparisons): Any kind of comparisons/comparators (such as } \\
\text { age, gender, years of teaching experience) } \\
\text { O (outcomes): Knowledge and attitudes concerning dental trauma } \\
\text { S (study type): Primary, original study (any study design included) }\end{array}$ \\
\hline
\end{tabular}


Table 1. Cont.

\begin{tabular}{|c|c|}
\hline Search Strategy Item & Search Strategy Details \\
\hline Exclusion criteria & $\begin{array}{l}\text { P: Teachers not teaching physical education, coaches, athletes, parents, reports } \\
\text { where physical education teachers were combined with teachers of other } \\
\text { disciplines, and it was not possible to extract data relevant only to the former } \\
\text { I: None } \\
\text { C: None } \\
\text { O: Outcomes not described in sufficient detail } \\
\text { S: Commentaries, expert opinions, letters to editor, editorials, original article } \\
\text { without sufficient details, reviews, conference abstracts or proceedings }\end{array}$ \\
\hline Time filter & None applied (search from inception) \\
\hline Language filter & None applied (any language) \\
\hline $\begin{array}{l}\text { Hand-searched target } \\
\text { journals }\end{array}$ & $\begin{array}{l}\text { "Dental Traumatology", "Endodontic \& Dental Traumatology", "International } \\
\text { Journal of Clinical Pediatric Dentistry", "International Journal of Dentistry", } \\
\text { "Journal of Indian Society of Pedodontics and Preventive Dentistry", "Journal of } \\
\text { Oral Health and Biosciences", "Pediatric Dentistry", "The British Dental Journal", } \\
\text { "The Journal of Contemporary Dental Practice" }\end{array}$ \\
\hline
\end{tabular}

\subsection{Study Selection}

Duplicate articles were initially eliminated manually. Two of the authors (K.T. and H.C.) independently screened the titles and abstracts of all unique hits for eligibility and resolved disagreements by consensus or involving a third author (N.L.B.). The full texts of the studies selected were then further screened for eligibility, and disagreements were again resolved by consensus or involving a third author (N.L.B.); reasons for exclusion of articles were recorded.

\subsection{Data Collection}

Two reviewers (K.T. and H.C.) independently collected data, using a pilot-tested extraction form, resolving disagreements by consensus or involving a third author (N.L.B.). Data extracted included participant characteristics (number, age, sex, years of teaching experience, first-aid training), study characteristics (years, country, tool design, number of items, question types, validation), and key outcomes.

\subsection{Quality Assessment}

Two researchers (K.T. and H.C.) assessed study quality using an adaptation of the techniques of Downs and Black [28].

The Downs and Black checklist provides an overall quality index and four sub-scale assessments of quality including reporting, external quality, internal validity-bias, and internal validity-confounding [28]. None of the studies identified were randomized controlled trials (RCTs) and only baseline or pre-intervention data were extracted from intervention studies.

Under "main findings," the item "intervention described" was taken to mean that the questionnaire was administered appropriately. Items related to confounders were scored "not applicable" if the primary outcome was a simple description of first-aid dental trauma knowledge. 
For intervention studies, when the researchers (K.T. and H.C.) were not sure that the control group had not received specific information related to dental trauma management during the study's intervention, the item related to confounders was rated as 'zero'.

Under the category "tool", an additional item assessing adequate validation of the questionnaire was included.

Validity was assessed according to five domains central to a sound and reliable instrument:

(i) face validity;

(ii) pre- or pilot testing;

(iii) content validity (review or evaluation of the instrument by experts);

(iv) test-retest reliability (measured by computing the Cronbach's $\alpha$ coefficient); and

(v) internal consistency (measured by computing the intra-class correlation and/or the Cronbach's $\alpha$ coefficient).

One point was awarded for each component of validation, yielding a maximum potential score of 14 .

\subsection{Meta-Analysis and Meta-Regressions}

When items were sufficiently comparable, a meta-analysis was performed utilizing the commercial software "Comprehensive Meta-Analysis" (CMA for Windows, version 3, Biostat, Englewood, NJ 2013, USA).

Prevalence rates were pooled. Effect size was calculated choosing a fixed-effect or a random-effect model, depending on the amount of heterogeneity (assessed by means of $\mathrm{I}^{2}$ statistics). If $\mathrm{I}^{2}>50 \%$, the DerSimonian-Laird random-effect model was preferred and applied.

Evidence of publication bias was investigated by visually inspecting the funnel plot and by conducting a trim-and-fill analysis [29]. The latter provides estimation of the number of missing studies that might exist in a meta-analysis and the effect that these studies might have had on its outcome [29].

Meta-regressions were performed in order to shed light on the determinants of effect size and heterogeneity among studies.

Forest plots were generated utilizing the commercial software MedCalc version 18.11.3 for Windows (MedCalc Software bvba, Ostend, Belgium).

\section{Results}

\subsection{Study Selection}

Out of a sample of 30 initial hits, 13 remained after exclusion of duplicates and the screening of titles and abstracts (Figure 1); 7 of these articles finally met our above-mentioned specific criteria for inclusion. A screening of reference lists and a search of Google Scholar added eight further articles, for a total of 15 . 


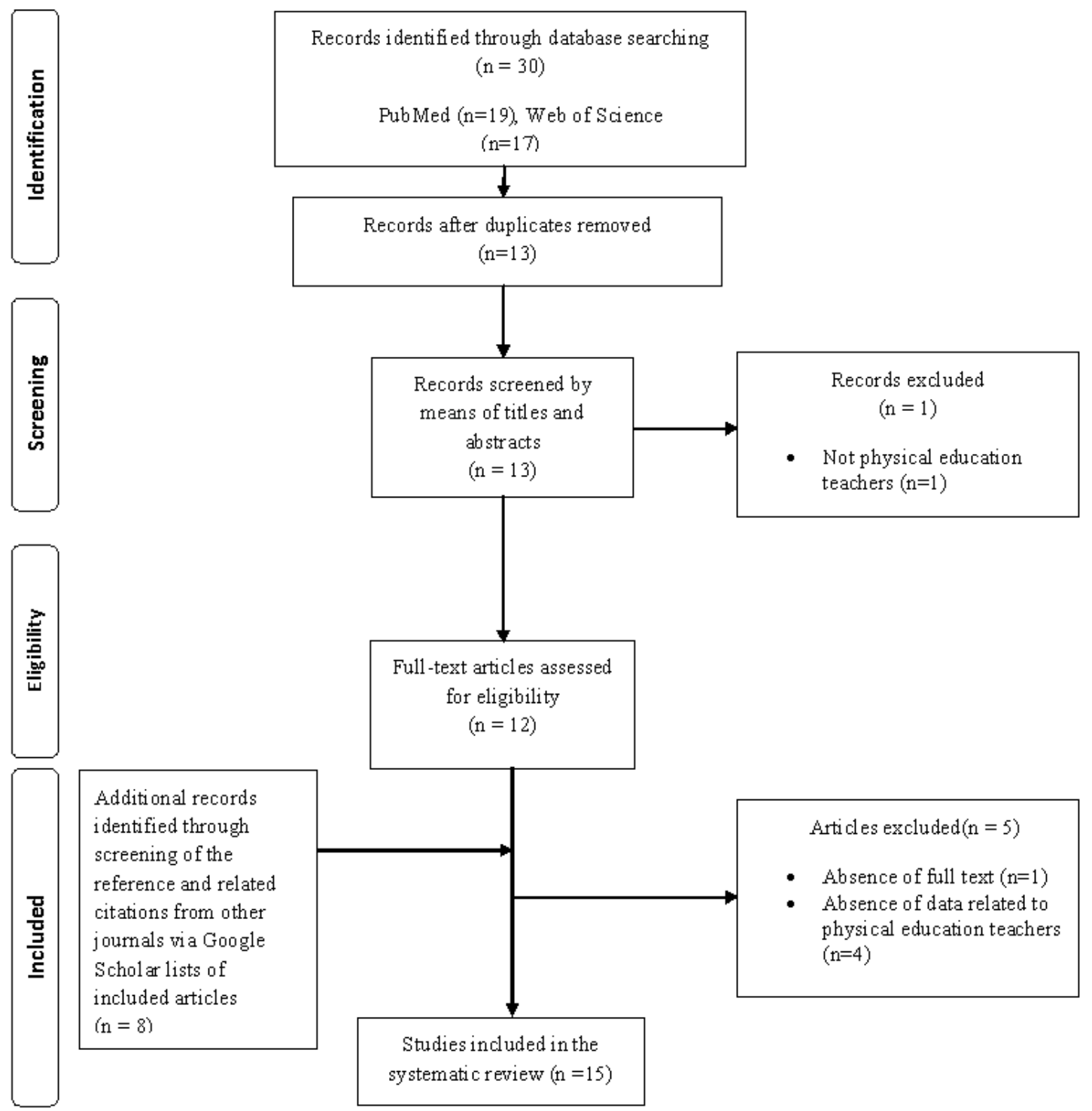

Figure 1. The process of study retrieval, selection and inclusion adopted in the present systematic review, meta-analysis and meta-regressions.

\subsection{Study Characteristics}

Characteristics of the 15 included studies are presented in Table 2. 
Table 2. A summary of studies assessing first-aid dental trauma knowledge in physical education teachers.

\begin{tabular}{|c|c|c|c|c|c|c|c|c|c|c|}
\hline \multirow{2}{*}{$\begin{array}{l}\text { Reference } \\
\text { (Author, Year, } \\
\text { Country) }\end{array}$} & \multirow[b]{2}{*}{ N (Sex) } & \multirow[b]{2}{*}{$\begin{array}{l}\text { Teaching } \\
\text { Experience }\end{array}$} & \multirow[b]{2}{*}{$\begin{array}{l}\text { Level of } \\
\text { Teaching }\end{array}$} & \multirow[b]{2}{*}{ Age (Years) } & \multirow[b]{2}{*}{$\begin{array}{l}\text { First-Aid } \\
\text { Training }\end{array}$} & \multirow{2}{*}{$\begin{array}{l}\text { Tool } \\
\text { Design }\end{array}$} & \multicolumn{3}{|c|}{ Questionnaire Summary } & \multirow{2}{*}{$\begin{array}{l}\text { Knowledge/Attitude and Correct/ } \\
\text { Incorrect Answers (\%) }\end{array}$} \\
\hline & & & & & & & $\begin{array}{l}\text { Number } \\
\text { of Items }\end{array}$ & $\begin{array}{l}\text { Question } \\
\text { Type }\end{array}$ & Validation & \\
\hline $\begin{array}{l}\text { Newman and } \\
\text { Crawford } \\
\text { (1991) [26]; } \\
\text { England }\end{array}$ & $\begin{array}{l}66(45 \mathrm{M} \\
21 \mathrm{~F})\end{array}$ & $\begin{array}{l}37 \text { teachers } \\
\text { between } 6 \\
\text { and } 30 \text { years }\end{array}$ & $\begin{array}{c}\text { 9\%: Junior } \\
\text { school. 38\%: } \\
\text { Middle } \\
\text { school. 48\%: } \\
\text { senior } \\
\text { school. }\end{array}$ & NM & $\begin{array}{l}91 \% \text { had been } \\
\text { trained in } \\
\text { first-aid }\end{array}$ & SDQ & 3 & Multiple-choice & $\begin{array}{c}\text { Not } \\
\text { validated }\end{array}$ & $\begin{array}{l}\text { Questions related to tooth fracture: } 42 / 66(64 \%) \\
\text { gave correct answer. } \\
\text { Questions related to tooth avulsion: 28/66 (43\%) } \\
\text { gave appropriate answer. }\end{array}$ \\
\hline $\begin{array}{l}\text { Chan et al. } \\
\text { (2001) [37]; } \\
\text { Hong Kong }\end{array}$ & $\begin{array}{l}166(94 \\
M, 72 \text { F) }\end{array}$ & $\begin{array}{l}139(84 \%)> \\
5 \text { years }\end{array}$ & $\begin{array}{l}\text { Secondary } \\
\text { school }\end{array}$ & $\begin{array}{l}49 \text { between } \\
20-29 \text { years; } \\
73 \text { between } \\
30-39 \text { years; } \\
36 \text { between } \\
40-49 \text { years; } \\
8 \text { aged } \\
50 \text { years and } \\
\text { above }\end{array}$ & $\begin{array}{l}165(99 \%) ; \\
8 \text { recalled the } \\
\text { emergency } \\
\text { management of } \\
\text { dental trauma as } \\
\text { being covered. } \\
127 \text { replied that } \\
\text { they had not } \\
\text { received } \\
\text { training. } \\
30 \text { teachers were } \\
\text { unsure }\end{array}$ & MEQ & 3 & Close-ended & $\begin{array}{c}\text { Not } \\
\text { validated }\end{array}$ & $\begin{array}{l}\text { Concerning the management of tooth fracture, } \\
118 / 166(71 \%) \text { of PE teachers gave an } \\
\text { appropriate answer. } \\
\text { 29/166 (17\%) of the respondents were able to } \\
\text { indicate the appropriate management for an } \\
\text { avulsed tooth. } \\
\text { 102/166 (61\%) of the respondents indicated it was } \\
\text { "very urgent" to seek professional assistance if a } \\
\text { permanent tooth has been avulsed, but they had } \\
\text { little knowledge of the correct procedures for } \\
\text { replanting or transporting avulsed teeth. } \\
\text { 15/166 (9\%) of the respondents pointed out that } \\
\text { milk was the medium of choice for transporting } \\
\text { avulsed teeth. }\end{array}$ \\
\hline $\begin{array}{l}\text { Holan et al. } \\
\text { (2006) [42]; } \\
\text { Israel }\end{array}$ & $\begin{array}{c}126(29 \\
\text { M, 32 F, } 5 \\
\text { NM) }\end{array}$ & NM & NM & NM & NM & SDQ & 2 & Multiple-choice & $\begin{array}{c}\text { Not } \\
\text { validated }\end{array}$ & $\begin{array}{l}\text { - 20/126 (16\%) of PE teachers provided correct } \\
\text { answers when asked about the best immediate } \\
\text { treatment of an avulsed tooth. } \\
\text { 24/126 (19\%) of the respondents would replant an } \\
\text { avulsed tooth by themselves. } \\
\text { 14/126 (11\%) of the respondents provided correct } \\
\text { responses about the best medium to transport } \\
\text { a tooth. }\end{array}$ \\
\hline
\end{tabular}


Table 2. Cont

\begin{tabular}{|c|c|c|c|c|c|c|c|c|c|c|}
\hline \multirow{2}{*}{$\begin{array}{l}\text { Reference } \\
\text { (Author, Year, } \\
\text { Country) }\end{array}$} & \multirow[b]{2}{*}{ N (Sex) } & \multirow{2}{*}{$\begin{array}{l}\text { Teaching } \\
\text { Experience }\end{array}$} & \multirow{2}{*}{$\begin{array}{l}\text { Level of } \\
\text { Teaching }\end{array}$} & \multirow[b]{2}{*}{ Age (Years) } & \multirow{2}{*}{$\begin{array}{l}\text { First-Aid } \\
\text { Training }\end{array}$} & \multirow{2}{*}{$\begin{array}{l}\text { Tool } \\
\text { Design }\end{array}$} & \multicolumn{3}{|c|}{ Questionnaire Summary } & \multirow{2}{*}{$\begin{array}{l}\text { Knowledge/Attitude and Correct/ } \\
\text { Incorrect Answers (\%) }\end{array}$} \\
\hline & & & & & & & $\begin{array}{l}\text { Number } \\
\text { of Items }\end{array}$ & $\begin{array}{l}\text { Question } \\
\text { Type }\end{array}$ & Validation & \\
\hline $\begin{array}{l}\text { Granville-Garcia } \\
\text { et al. (2007) [32]; } \\
\text { Brazil }\end{array}$ & $\begin{array}{l}79(47 \mathrm{M} \\
32 \mathrm{~F})\end{array}$ & $\begin{array}{c}77.2 \% \\
\text { between } 11 \\
\text { and } 25 \text { years }\end{array}$ & NM & NM & None & Interview & NA & NA & NA & $\begin{array}{l}\text { - } 16 / 79(20 \%) \text { of the teachers knew what dental } \\
\text { trauma was. } \\
\text { In the case of tooth avulsion, } 15 / 79(19 \%) \text { of the } \\
\text { respondents would not know what to do and } \\
64 / 79(81 \%) \text { of them would wash the tooth in } \\
\text { running tap water. } \\
68 / 79(86 \%) \text { of them mentioned that treatment } \\
\text { should be sought immediately. } \\
\text { 79/79 }(100 \%) \text { of them reported that they would } \\
\text { wrap the tooth in a napkin until the child received } \\
\text { care and } 21 / 79(27 \%) \text { of them answered that they } \\
\text { would recommend the use of analgesics in case } \\
\text { of pain. }\end{array}$ \\
\hline $\begin{array}{c}\text { Mohandas and } \\
\text { Ghandan (2009) } \\
\text { [35]; India }\end{array}$ & $\begin{array}{l}580(402 \\
\mathrm{M} ; 178 \mathrm{~F})\end{array}$ & NM & $\begin{array}{l}\text { Primary, } \\
\text { middle, and } \\
\text { high schools }\end{array}$ & $\begin{array}{l}56(10 \%) \\
\text { were under } \\
25 \text { years of } \\
\text { age, } 185 \\
(32 \%) \text { were } \\
\text { between } 25 \\
\text { and } 34 \text { years, } \\
244(42 \%) \\
\text { were } \\
\text { between } 35 \\
\text { and } 44 \text { years } \\
\text { of age, } 62 \\
(11 \%) \text { were } \\
\text { between } 45 \\
\text { and } 54 \text { years } \\
\text { and above } \\
\text { age group. } \\
33(6 \%) \text { were } \\
\text { above } 55 \\
\text { years }\end{array}$ & $\begin{array}{l}527(91 \%) \text { had } \\
\text { first-aid training. } \\
24(4 \%) \text { of them } \\
\text { had no first-aid } \\
\text { training }\end{array}$ & SDQ & 3 & Multiple-choice & $\begin{array}{c}\text { Not } \\
\text { validated }\end{array}$ & $\begin{array}{l}\text { - } 162 / 580(28 \%) \text { of PE teachers agreed to replant by } \\
\text { themselves the avulsed permanent tooth. } \\
\text { - } 288 / 580 \text { ( } 50 \% \text { ) of the respondents thought they } \\
\text { should seek professional help immediately. } \\
\text { - All the } 580(100 \%) \text { PE teachers answered to seek } \\
\text { professional help at least before next day. } \\
\text { - } 11 / 580(22 \%) \text { of PE teachers would keep the tooth } \\
\text { in milk. } \\
\text { The majority of PE teachers ( } 296 / 580 ; 51 \%) \text { would } \\
\text { refer to a dental clinic in the case of dental injury. } \\
\text { 363/580 (63\%) of PE teachers felt that the avulsed } \\
\text { tooth should be replanted. } \\
\text { When questioned regarding cleaning the soiled } \\
\text { avulsed tooth, } 262 / 580 \text { ( } 45 \%) \text { of them would rinse } \\
\text { the tooth under tap water. } \\
\text { 15/580 ( } 32.5 \%) \text { of the respondents felt that they } \\
\text { would put the tooth straight back into the socket. }\end{array}$ \\
\hline
\end{tabular}


Table 2. Cont

\begin{tabular}{|c|c|c|c|c|c|c|c|c|c|c|}
\hline \multirow{2}{*}{$\begin{array}{l}\text { Reference } \\
\text { (Author, Year, } \\
\text { Country) }\end{array}$} & \multirow[b]{2}{*}{ N (Sex) } & \multirow{2}{*}{$\begin{array}{l}\text { Teaching } \\
\text { Experience }\end{array}$} & \multirow{2}{*}{$\begin{array}{l}\text { Level of } \\
\text { Teaching }\end{array}$} & \multirow[b]{2}{*}{ Age (Years) } & \multirow{2}{*}{$\begin{array}{l}\text { First-Aid } \\
\text { Training }\end{array}$} & \multirow{2}{*}{$\begin{array}{l}\text { Tool } \\
\text { Design }\end{array}$} & \multicolumn{3}{|c|}{ Questionnaire Summary } & \multirow{2}{*}{$\begin{array}{l}\text { Knowledge/Attitude and Correct/ } \\
\text { Incorrect Answers (\%) }\end{array}$} \\
\hline & & & & & & & $\begin{array}{l}\text { Number } \\
\text { of Items }\end{array}$ & $\begin{array}{l}\text { Question } \\
\text { Type }\end{array}$ & Validation & \\
\hline $\begin{array}{l}\text { Subramaniam et } \\
\text { al. (2011) [34]; } \\
\text { India }\end{array}$ & $\begin{array}{l}109 \\
(75 \mathrm{M} \\
34 \mathrm{~F})\end{array}$ & $\begin{array}{l}32 \%(\mathrm{n}=35) \\
\text { of the } \\
\text { respondents } \\
\text { had less than } \\
\text { five years' } \\
\text { experience }\end{array}$ & NM & $\begin{array}{c}32 \%(\mathrm{n}=38) \\
\text { were aged } \\
\text { between } 20 \\
\text { and } 30 \text { years } \\
\text { and } 388 \% \\
(\mathrm{n}=41) \\
\text { were aged } \\
\text { between } 31 \\
\text { and } 40 \text { years }\end{array}$ & $\begin{array}{l}\text { Majority of the } \\
\text { respondents } \\
(87 \%) \text { said that } \\
\text { their training } \\
\text { included } \\
\text { first-aid training. } \\
\text { Only } 10 \% \\
\text { recalled that } \\
\text { their course } \\
\text { covered } \\
\text { management of } \\
\text { dental trauma }\end{array}$ & NM & MEQ & Close-ended & $\begin{array}{c}\text { Not } \\
\text { validated }\end{array}$ & 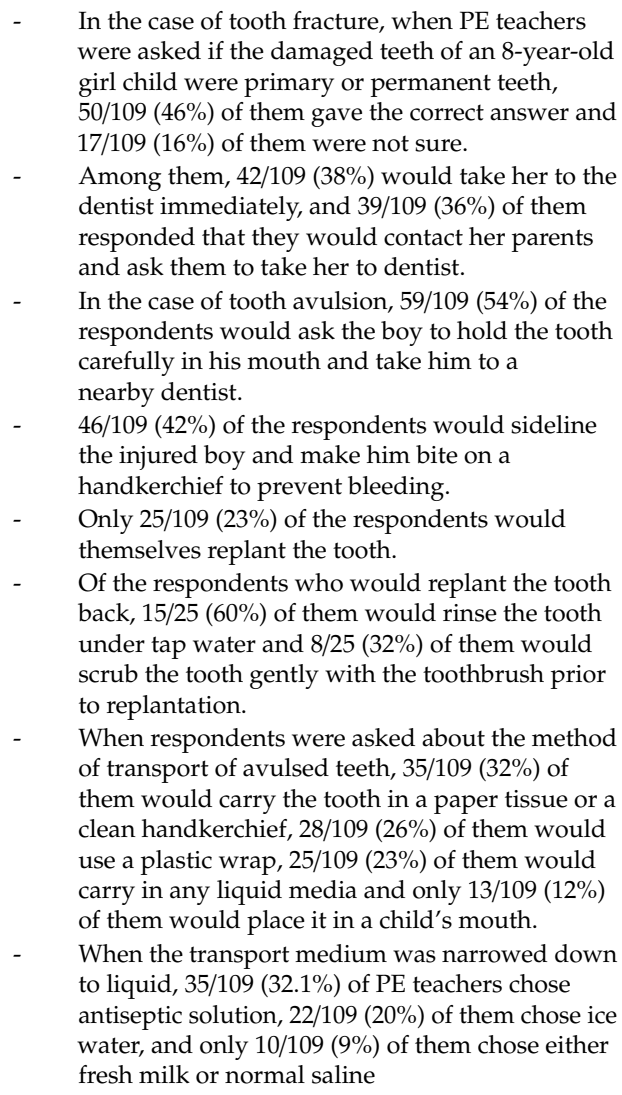 \\
\hline
\end{tabular}


Table 2. Cont

\begin{tabular}{|c|c|c|c|c|c|c|c|c|c|c|}
\hline \multirow{2}{*}{$\begin{array}{l}\text { Reference } \\
\text { (Author, Year, } \\
\text { Country) }\end{array}$} & \multirow[b]{2}{*}{ N (Sex) } & \multirow{2}{*}{$\begin{array}{l}\text { Teaching } \\
\text { Experience }\end{array}$} & \multirow{2}{*}{$\begin{array}{l}\text { Level of } \\
\text { Teaching }\end{array}$} & \multirow[b]{2}{*}{ Age (Years) } & \multirow{2}{*}{$\begin{array}{l}\text { First-Aid } \\
\text { Training }\end{array}$} & \multirow{2}{*}{$\begin{array}{l}\text { Tool } \\
\text { Design }\end{array}$} & \multicolumn{3}{|c|}{ Questionnaire Summary } & \multirow{2}{*}{$\begin{array}{l}\text { Knowledge/Attitude and Correct/ } \\
\text { Incorrect Answers (\%) }\end{array}$} \\
\hline & & & & & & & $\begin{array}{l}\text { Number } \\
\text { of Items }\end{array}$ & $\begin{array}{c}\text { Question } \\
\text { Type }\end{array}$ & Validation & \\
\hline $\begin{array}{c}\text { Jorge et al. } \\
\text { (2009) [30]; } \\
\text { Brazil }\end{array}$ & 53 & NM & Faculty & $\begin{array}{l}\text { mean age }= \\
41 \text { years }\end{array}$ & NM & MEQ & 3 & Multiple-choice & $\begin{array}{c}\text { Not } \\
\text { validated }\end{array}$ & $\begin{array}{l}\text { - } 49 / 53(92 \%) \text { of the respondents defined correctly } \\
\text { tooth replantation. } \\
\text { Immediate replantation was cited by } 7 / 53(13 \%) \text { of } \\
\text { the respondents. } \\
\text { Only } 10 / 53(19 \%) \text { of them will place the tooth in a } \\
\text { liquid medium. } \\
\text { Only } 6 / 53(11 \%) \text { of them will send the student to } \\
\text { the dentist. } \\
\text { Only } 12 / 53(23 \%) \text { of them will send the student } \\
\text { with the tooth to the dentist. } \\
\text { - Only } 10 / 53(19 \%) \text { of them will store the tooth. } \\
\text { - } 31 / 53(58 \%) \text { of them reported falsely that is } \\
\text { possible to store the tooth more than } 360 \text { min. } \\
\text { Only } 9 / 53(16 \%) \text { considered milk as a suitable } \\
\text { storage medium. }\end{array}$ \\
\hline $\begin{array}{c}\text { Vergotine and } \\
\text { Govoni (2010) } \\
\text { [40]; USA }\end{array}$ & 119 & $\begin{array}{c}50 \%>10 \\
\text { years } \\
\text { teaching } \\
\text { experience }\end{array}$ & $\begin{array}{l}\text { High and } \\
\text { middle } \\
\text { schools }\end{array}$ & NM & $\begin{array}{l}72 \% \text { had specific } \\
\text { trauma training } \\
\text { for athletic } \\
\text { setting with } 62 \% \\
\text { of teachers } \\
\text { having dental } \\
\text { component } \\
\text { included in } \\
\text { training }\end{array}$ & SDQ & NM & $\begin{array}{l}\text { Multiple-choice } \\
\text { questions }\end{array}$ & $\begin{array}{c}\text { Not } \\
\text { validated }\end{array}$ & $\begin{array}{l}\text { For the urgency of treatment for tooth fractures, } \\
\text { 63/119 }(53 \%) \text { of PE teachers responded correctly. } \\
\text { With regards to avulsions, } 55 / 119(46 \%) \text { of PE } \\
\text { teachers responded that immediate professional } \\
\text { assistance was needed. } \\
\text { Only } 8 / 119(7 \%) \text { of PE teachers would replant an } \\
\text { avulsed tooth. } \\
\text { Milk was chosen as a transportation medium for } \\
\text { an avulsed tooth by } 27 / 119(23 \%) \text { of PE teachers. }\end{array}$ \\
\hline
\end{tabular}


Table 2. Cont

\begin{tabular}{|c|c|c|c|c|c|c|c|c|c|c|}
\hline \multirow{2}{*}{$\begin{array}{c}\text { Reference } \\
\text { (Author, Year, } \\
\text { Country) }\end{array}$} & \multirow[b]{2}{*}{$N($ Sex $)$} & \multirow{2}{*}{$\begin{array}{l}\text { Teaching } \\
\text { Experience }\end{array}$} & \multirow{2}{*}{$\begin{array}{l}\text { Level of } \\
\text { Teaching }\end{array}$} & \multirow[b]{2}{*}{ Age (Years) } & \multirow{2}{*}{$\begin{array}{l}\text { First-Aid } \\
\text { Training }\end{array}$} & \multirow{2}{*}{$\begin{array}{l}\text { Tool } \\
\text { Design }\end{array}$} & \multicolumn{3}{|c|}{ Questionnaire Summary } & \multirow{2}{*}{$\begin{array}{l}\text { Knowledge/Attitude and Correct/ } \\
\text { Incorrect Answers (\%) }\end{array}$} \\
\hline & & & & & & & $\begin{array}{l}\text { Number } \\
\text { of Items }\end{array}$ & $\begin{array}{l}\text { Question } \\
\text { Type }\end{array}$ & Validation & \\
\hline $\begin{array}{l}\text { Pagliarin et al. } \\
\text { (2011) [31]; } \\
\text { Brazil }\end{array}$ & 102 & $\begin{array}{c}\text { Mean length } \\
\text { working as a } \\
\text { teacher was } \\
19.61 \text { years }\end{array}$ & NM & $\begin{array}{c}\text { Mean age } \\
\text { was } 46 \text { years } \\
\text { (range: } 33 \text { to } \\
59 \text { years) }\end{array}$ & $\begin{array}{c}24(23 \%) \\
\text { reported to have } \\
\text { received prior } \\
\text { information on } \\
\text { dental trauma }\end{array}$ & SDQ & 2 & $\begin{array}{l}\text { Multiple-choice } \\
\text { questions }\end{array}$ & $\begin{array}{c}\text { Not } \\
\text { validated }\end{array}$ & $\begin{array}{l}\text { When PE teachers were asked about the first } \\
\text { action to be taken if faced with an avulsed tooth, } \\
\text { only } 13 / 102(13 \%) \text { of them informed they would } \\
\text { attempt to replant the tooth, } 52 / 102 \text { (51\%) of them } \\
\text { did not know the answer. } \\
24 / 102(243.5 \%) \text { of PE teachers considered } 30 \text { min } \\
\text { to be an adequate amount of time, } 14 / 102(14 \%) \text { of } \\
\text { them } 1 \mathrm{~h}, 8 / 102(8 \%) \text { of them up to } 2 \mathrm{~h} \text {, and } 4 / 102 \\
\text { (4\%) of them believed that time was not an } \\
\text { important issue in the management of } \\
\text { avulsed teeth. } \\
\text { The use of mouthguards as a tool to prevent } \\
\text { dental trauma was considered valid by } 71 / 102 \\
\text { (70\%) of the respondents; the remainder did not } \\
\text { believe that such an initiative could have any } \\
\text { effect on the prevention of sports-related trauma. }\end{array}$ \\
\hline $\begin{array}{l}\text { Lecor et al. } \\
\text { (2013) [38]; } \\
\text { Sénégal }\end{array}$ & $\begin{array}{l}162(131 \\
\mathrm{M} ; 31 \mathrm{~F})\end{array}$ & $\begin{array}{l}25 \% \\
\text { between } 1 \\
\text { and } 5 \text { years; } \\
26 \% \\
\text { between } 6 \\
\text { and } 10 \text { years; } \\
7 \% \text { between } \\
16 \text { and } 20 \\
\text { years; } 15 \% \\
\text { between } 11 \\
\text { and } 15 \text { years; } \\
15 \% \text { more } \\
\text { than } 20 \\
\text { years; } 2 \% \\
\text { less than } 1 \\
\text { year }\end{array}$ & NM & $\begin{array}{c}10 \% \text { did not } \\
\text { mention; } \\
61 \% \\
\text { between } \\
20-40 \text { years; } \\
33 \% \\
\text { between } \\
41-60 \text { years; } \\
2 \% \text { less than } \\
20 \text { years; } 6 \\
\text { teachers did } \\
\text { not mention }\end{array}$ & NM & MEQ & 3 & Multiple-choice & $\begin{array}{c}\text { Not } \\
\text { validated }\end{array}$ & $\begin{array}{l}\text { - } 125 / 162 \text { ( } 77 \% \text { ) of PE teachers considered dental } \\
\text { avulsion as an emergency. } \\
\text { - Attitudes to a case of dental avulsion: } 52 / 162 \\
\text { (32\%) of PE teachers had decided to send the } \\
\text { student to a dental surgeon and } 61 / 162(38 \%) \text { of } \\
\text { them had chosen to contact the nearest } \\
\text { dental service. } \\
\text { A systematic rinse of the tooth was chosen by } \\
\text { 61/162 (38\%) of PE teachers. } \\
\text { The most used rinsing solution was running } \\
\text { water chosen by } 71 / 162(44 \%) \text { of PE teachers } \\
\text { followed by antiseptic solution chosen by } 18 / 162 \\
\text { (11\%) of the respondents. } \\
\text { 9/162 (6\%) would attempt to relocate the tooth at } \\
\text { the accident site and the remaining (143/162, 88\%) } \\
\text { would not do it. } \\
\text { Paper and compresses were chosen by } 49 / 162 \\
\text { (30\%) of PE teachers. } \\
\text { Liquid media accounted for only } 16 / 162(10 \%) \text { of } \\
\text { PE teachers. Among them, running water was the } \\
\text { most common with } 87 / 162(54 \%) \text {, chilled water } \\
29 / 162(18 \%) \text { antiseptic } 29 / 162(18 \%) \text { and no } \\
\text { teacher chose milk. }\end{array}$ \\
\hline
\end{tabular}


Table 2. Cont

\begin{tabular}{|c|c|c|c|c|c|c|c|c|c|c|}
\hline \multirow{2}{*}{$\begin{array}{l}\text { Reference } \\
\text { (Author, Year, } \\
\text { Country) }\end{array}$} & \multirow[b]{2}{*}{$\mathbf{N}($ Sex) } & \multirow{2}{*}{$\begin{array}{l}\text { Teaching } \\
\text { Experience }\end{array}$} & \multirow{2}{*}{$\begin{array}{l}\text { Level of } \\
\text { Teaching }\end{array}$} & \multirow[b]{2}{*}{ Age (Years) } & \multirow{2}{*}{$\begin{array}{l}\text { First-Aid } \\
\text { Training }\end{array}$} & \multirow{2}{*}{$\begin{array}{l}\text { Tool } \\
\text { Design }\end{array}$} & \multicolumn{3}{|c|}{ Questionnaire Summary } & \multirow{2}{*}{$\begin{array}{l}\text { Knowledge/Attitude and Correct/ } \\
\text { Incorrect Answers (\%) }\end{array}$} \\
\hline & & & & & & & $\begin{array}{l}\text { Number } \\
\text { of Items }\end{array}$ & $\begin{array}{l}\text { Question } \\
\text { Type }\end{array}$ & Validation & \\
\hline $\begin{array}{l}\text { Panahi et al. } \\
\text { (2014) [39]; Iran }\end{array}$ & $\begin{array}{c}165(86 \\
M \text { and } 70 \\
\text { F) }\end{array}$ & $\begin{array}{l}8 \text { years' } \\
\text { work } \\
\text { experiences }\end{array}$ & $\begin{array}{l}\text { Primary } \\
\text { schools }\end{array}$ & $\begin{array}{l}\text { The mean } \\
\text { age of the } \\
\text { subjects was } \\
32 \text { years }\end{array}$ & NM & MEQ & 3 & $\begin{array}{l}\text { Multiple } \\
\text { choice } \\
\text { questions }\end{array}$ & $\begin{array}{l}\text { Partially } \\
\text { validated }\end{array}$ & $\begin{array}{l}\text { 111/165 }(67 \%) \text { of the tutors had mid-level } \\
\text { knowledge regarding types of traumas to teeth. } \\
\text { 106/165 }(64 \%) \text { had a low level of knowledge } \\
\text { regarding the process of avulsed teeth protection. } \\
\text { Normal saline and alcohol were the most } \\
\text { commonly chosen substances by teachers for } \\
\text { rinsing and transferring the avulsed tooth. }\end{array}$ \\
\hline $\begin{array}{c}\text { Bahandary and } \\
\text { Shetty (2014) } \\
\text { [41]; India }\end{array}$ & $\begin{array}{l}243(165 \\
\mathrm{M} ; 59 \mathrm{~F})\end{array}$ & $\begin{array}{l}93 \% \text { had } \\
\text { more than } 5 \\
\text { years } \\
\text { teaching } \\
\text { experience }\end{array}$ & NM & $\begin{array}{l}41 \% \text { were in } \\
\text { the age } \\
\text { group of } \\
40-49 \text { years }\end{array}$ & $\begin{array}{l}94 \% \text { had } \\
\text { first-aid training. } \\
\text { However, only } \\
25 \% \text { of them had } \\
\text { training } \\
\text { regarding } \\
\text { management of } \\
\text { dental trauma }\end{array}$ & MEQ & 3 & Close-ended & $\begin{array}{l}\text { Partially } \\
\text { validated }\end{array}$ & $\begin{array}{l}\text { When asked about tooth fracture, only } 83 / 243 \\
(34 \%) \text { responded correctly that they would place } \\
\text { the tooth back and take the child to dentist. } \\
\text { When asked about avulsion due to trauma, only } \\
46 / 243(19 \%) \text { of PE teachers responded correctly } \\
\text { that they would place the tooth back and take the } \\
\text { child to dentist. } \\
\text { 199/243 }(82 \%) \text { responded that they need further } \\
\text { training in dental training management. } \\
112 / 243(46 \%) \text { reported that primary teeth do not } \\
\text { need to be replanted. } \\
\text { 29/243 (12\%) responded correctly that the tooth } \\
\text { should be put back into the socket without } \\
\text { scribbling or washing. } \\
129 / 243(53 \%) \text { responded correctly that the tap } \\
\text { water is the best washing liquid. }\end{array}$ \\
\hline $\begin{array}{l}\text { Singh et al. } \\
\text { (2015) [36]; India }\end{array}$ & 165 & NM & NM & NM & NM & SDQ & 3 & Multiple-choice & $\begin{array}{c}\text { Not } \\
\text { validated }\end{array}$ & $\begin{array}{l}\text { - } 118 / 165(72 \%) \text { gave correct answer when asked } \\
\text { about dental trauma management. } \\
\text { Regarding the extra alveolar time limit, } 111 / 165 \\
(67 \%) \text { gave the correct answer. } \\
\text { 136/165 (82\%) gave correct answer when asked } \\
\text { about the storage medium for the avulsed teeth. } \\
\text { 12/165 (7\%) gave correct answer when asked } \\
\text { about preference to trauma referral. }\end{array}$ \\
\hline
\end{tabular}


Table 2. Cont

\begin{tabular}{|c|c|c|c|c|c|c|c|c|c|c|}
\hline \multirow{2}{*}{$\begin{array}{l}\text { Reference } \\
\text { (Author, Year, } \\
\text { Country) }\end{array}$} & \multirow[b]{2}{*}{$\mathbf{N}($ Sex) } & \multirow{2}{*}{$\begin{array}{l}\text { Teaching } \\
\text { Experience }\end{array}$} & \multirow[b]{2}{*}{$\begin{array}{l}\text { Level of } \\
\text { Teaching }\end{array}$} & \multirow[b]{2}{*}{ Age (Years) } & \multirow[b]{2}{*}{$\begin{array}{l}\text { First-Aid } \\
\text { Training }\end{array}$} & \multirow{2}{*}{$\begin{array}{l}\text { Tool } \\
\text { Design }\end{array}$} & \multicolumn{3}{|c|}{ Questionnaire Summary } & \multirow[b]{2}{*}{$\begin{array}{l}\text { Knowledge/Attitude and Correct/ } \\
\text { Incorrect Answers (\%) }\end{array}$} \\
\hline & & & & & & & $\begin{array}{l}\text { Number } \\
\text { of Items }\end{array}$ & $\begin{array}{l}\text { Question } \\
\text { Type }\end{array}$ & Validation & \\
\hline $\begin{array}{l}\text { D'Assunção et } \\
\text { al. (2015) [33]; } \\
\text { Brazil }\end{array}$ & 103 & NM & NM & $\begin{array}{c}\text { Over } 18 \\
\text { years old }\end{array}$ & NM & MEQ & 3 & $\begin{array}{l}\text { Open and } \\
\text { closed, } \\
\text { dichotomous } \\
\text { and multiple } \\
\text { choice }\end{array}$ & $\begin{array}{c}\text { Not } \\
\text { validated }\end{array}$ & $\begin{array}{l}\text { - } 80 / 103(78 \%) \text { did not know the term } \\
\text { dental avulsion. } \\
\text { Regarding the most appropriate means to } \\
\text { transport an avulsed tooth, } 85 / 103(82 \%) \text { reported } \\
\text { that they could not perform the procedure } \\
\text { of reimplantation. } \\
\text { - Saline solution was most cited by the PE teachers } \\
58 / 103(56 \%) \text { and saliva } 3 / 103(3 \%) \text { was cited } \\
\text { the least. }\end{array}$ \\
\hline $\begin{array}{l}\text { Anand et al. } \\
\text { (2016) [43]; India }\end{array}$ & $\begin{array}{l}60(42 \mathrm{M} ; \\
18 \mathrm{~F})\end{array}$ & NM & NM & NM & NM & MEQ & 3 & Multiple-choice & $\begin{array}{c}\text { Not } \\
\text { validated }\end{array}$ & $\begin{array}{l}\text { - When asked about the first reaction on seeing the } \\
\text { child with trauma, only } 30 / 60(50 \%) \text { replied that } \\
\text { they would contact parents and carry the child to } \\
\text { the dentist nearby the school. } \\
\text { Regarding the knowledge about management of } \\
\text { tooth fracture, } 30 / 60(50 \%) \text { responded that broken } \\
\text { tooth piece cannot be reattached. } \\
\text { Regarding the replantation of avulsed tooth, } 30 / 60 \\
\text { (50\%) replied that it is not possible to replant the } \\
\text { tooth back into the socket. } \\
\text { 20/60 ( } 33 \%) \text { answered that they would wash it } \\
\text { under running tap water, and wrap it in a clean } \\
\text { cloth and carry to the dentist } \\
8 / 60(13 \%) \text { had belief that once a tooth is avulsed, } \\
\text { it is of no use. }\end{array}$ \\
\hline
\end{tabular}

Abbreviations: NM: Not mentioned, SDQ: Self-developed questionnaire, MEQ: Modified existing questionnaire, PE: Physical education, M = male, $\mathrm{F}=$ female. 
Most articles $(n=14)$ were published subsequent to 2000, but one was published in 1990. Fourteen [26,30-43] were descriptive studies; one [42] included an educational intervention, and only the baseline descriptive statistics from this article were used. Five of the studies were conducted in India [34-36,41,43], four in Brazil [30-33], and the remainder were from Hong Kong [37], Israel [42], Iran [39], England [26], United States of America [40], and Senegal [38]. The number of PE teachers involved ranged from 13 to 580, with a total of 2,040. Most articles $(n=9)$ referred to mixed-sex samples, but five failed to identify the sex of the teachers. Men were in the majority ( $67 \%$ versus $33 \%$ ) where sex was indicated. Ages ranged from 20 to 60 years, but six studies failed to report the age of participants.

The extent of first-aid training and its dental component varied widely between reports. Four studies $[26,34,35,37]$ indicated that $90 \%$ or more of teachers had received first-aid training; but only $\sim 5 \%[35,37]$ or $9 \%$ [34] recalled a dental component.

More in detail, Vergotine and Govoni [40] found that 86/119 (72\%) of PE teachers had received trauma training specific to the athletic setting, 53/119 (62\%) of them with a dental component. Pagliarin et al. [31] reported that $24 / 102(23 \%)$ of PE teachers had received information about dental trauma. Surprisingly, only 5/60 (8\%) of PE teachers in the study of Anand et al. [43] and none of those questioned by Granville-Garcia et al. [32] had received first-aid training.

Other reports $[33,36,38,39,42]$ did not indicate the extent of such training. The percentage of PE teachers with more than five years of professional experience was high in all studies where this was discussed [26,30-32,34,36-40].

Eight studies reported experience with dental injuries [32-35,37-39,43], in four reports, between $20 \%$ and $30 \%$ of teachers had either direct or indirect experience of dental injury $[33,37,39,43]$ and in other reports percentages ranged from 9\% [35] to 17\% [38], 33\% [40], 38\% [34], and 44\% [32].

Dental first-aid knowledge was assessed by questionnaire in 14 studies $[26,30,31,33,34,36-40,42,43]$ and by interview in one study [32].

Most of the questionnaires had not been validated [26,31,33-38,40,42], although one study gave a partial description of questionnaire validation [39].

Typically, questionnaires covered

(i). personal and professional data (sex, age, teaching experience, first-aid training background);

(ii) questions based on imaginary cases of dental injuries, and

(iii) multiple-choice questions on the management of avulsed and/or fractured teeth and the use of mouthguards.

Response formats included true/false, multiple choice, and open- and close-ended questions.

\subsection{Attitudes Regarding Dental Injuries}

When PE teachers that have witnessed a dental-injury event were asked about their immediate reaction, 14/27 (52\%) recognized the urgency of seeking professional assistance (e.g., dental surgeon) [34]. All of the respondents to Mohandes and Ghandan's survey [35] thought such a treatment was necessary, and $60 \%(102 / 166)$ of the teachers rated by Chan et al. [37] thought it was "very urgent" to seek professional assistance if a permanent tooth has been avulsed. Anand et al. [43] reported that 30/60 $(50 \%)$ of teachers would contact parents and carry the child to a nearby dentist, while $20 / 60(33 \%)$ would give the child a warm drink and call the parents. For Subramaniam et al. [34], 42/109 (38\%) of teachers would take the child to the dentist immediately, and a further 39/109 (36\%) would contact the parents and ask them to take him or her to the dentist. D’Assunção et al. [33] found that 70/103 (68\%) teachers believed that an avulsed tooth could be replaced; but 85/103 (82\%) reported that they could not themselves perform such a procedure.

Others also found that only a small percentage of teachers would attempt to replant the avulsed tooth themselves: 25/109 (23\%) [34], 24/126 (19\%) [42], 13/102 (13\%) [31], or 9/162 (6\%) [38]. Surprisingly, (51/162) $33 \%$ of teachers asked by Lecor et al. [38] would not even keep avulsed tooth, and 15/79 (19\%) of teachers, questioned by Granville-Garcia et al. [32], would not know what to do. 


\subsection{First-Aid Dental Trauma Knowledge}

The first study on this issue was by Newman and Crawford [26]; 42/66 (64\%) of teachers answered correctly concerning tooth fracture, but only $28 / 66(43 \%)$ responded appropriately about the avulsion of permanent teeth. Similarly, Chan et al. [37] found 118/166 (71\%) answering correctly about tooth fracture, but only 29/166 (17\%) knew the response for tooth avulsion. Anand et al. [43] noted that 30/60 $(50 \%)$ of teachers thought a broken tooth piece could not be reattached and that an avulsed tooth could not be replanted. Vergotine and Govoni [40] reported that only 63/119 (53\%) of PE teachers appreciated the need for urgency in the treatment of tooth fractures. Pagliarin et al. [31] found that most of the teachers would try to locate an avulsed tooth; of the remainder, 16/102 (16\%) would try to stop the bleeding with pressure (e.g., using a cloth), 13/102 (13\%) would try to replant the tooth, 8/102 (8\%) would call the child's parents or guardians, and 7/102 (7\%) would take the child to the dentist, not bothering about the avulsed tooth. However, among the teachers who would try to replant the tooth, 47/102 (46\%) were unaware of the correct procedures for reimplantation [31]. Panahi et al. [39] reported that $111 / 165(67 \%)$ of teachers had moderate information regarding dental trauma, but 106/165 (64\%) knew little or nothing about the best time for reimplantation of avulsed teeth, methods of cleaning the avulsed root surface, appropriate media for conserving the tooth, and techniques of reimplantation. Jorge et al. [30] found that $49 / 53(92 \%)$ teachers knew what tooth reimplantation was, and 22/53 (42\%) defined reimplantation correctly; however, immediate reimplantation was suggested by only 11/53 (21\%) of the group.

Among the teachers questioned by Holan et al. [42], only 20/162 (16\%) knew 'What is the best immediate treatment for an avulsed tooth?'. Bahandari and Shetty [41] observed that about 112/243 $(46 \%)$ of teachers did not believe a primary tooth needed to be replanted; however, $29 / 243(12 \%)$ correctly answered that the tooth should be put back into its socket without scrubbing or washing. In contrast, Ganville-Garcia et al. [32] found all teachers answering falsely that they would give the student a handkerchief or towel to bite and control bleeding. D'Assunção et al. [33] reported that $77 / 103(75 \%)$ of teachers thought that when a tooth was completely out of its socket, it must be picked up by the crown. Anand et al. [43] noted that 8/62 (13\%) believed that if a tooth was completely dislodged, it was of no use and should be discarded. Surprisingly, Singh et al. [36] had 117/165 (71\%) of teachers responding correctly to questions on dental trauma management.

Pooling studies regarding the knowledge of tooth fracture management, 52.6\% ((95\% CI 43.4 to 61.7), $\mathrm{I}^{2}=89.51 \%$ ) of participants gave a correct response. The forest plot is shown in Figure 2 .
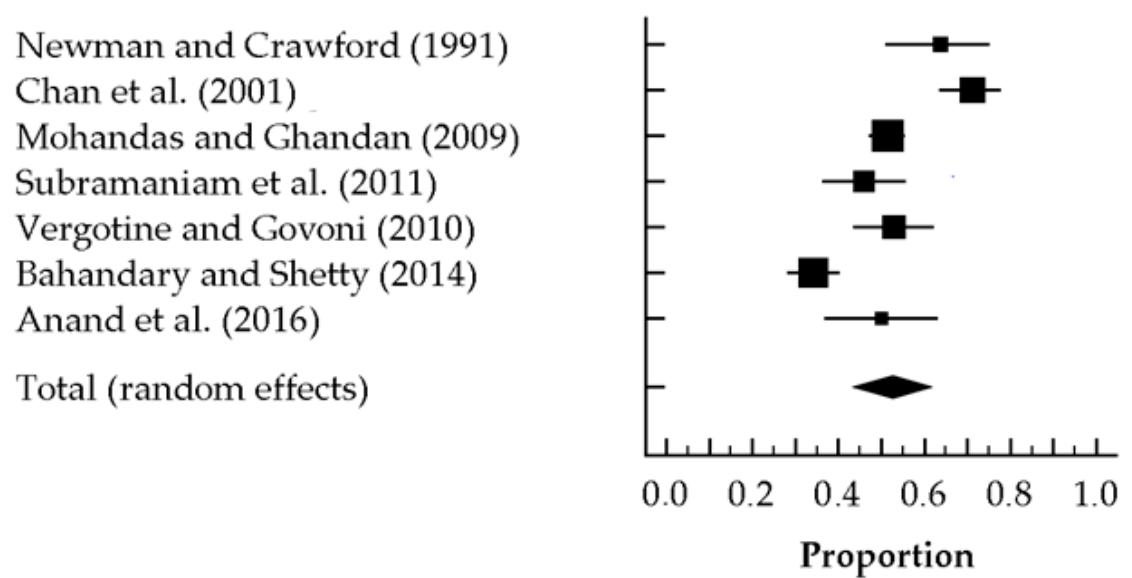

Figure 2. Forest plot of studies investigating the knowledge of tooth fracture among physical education teachers.

Evidence of publication bias could be detected, with two studies being trimmed, resulting in a "real" effect size of $47.3 \%$ ((95\% CI 37.3 to 56.8$), Q=104.66)$ (Figure 3). 
Funnel Plot of Standard Error by Logit event rate

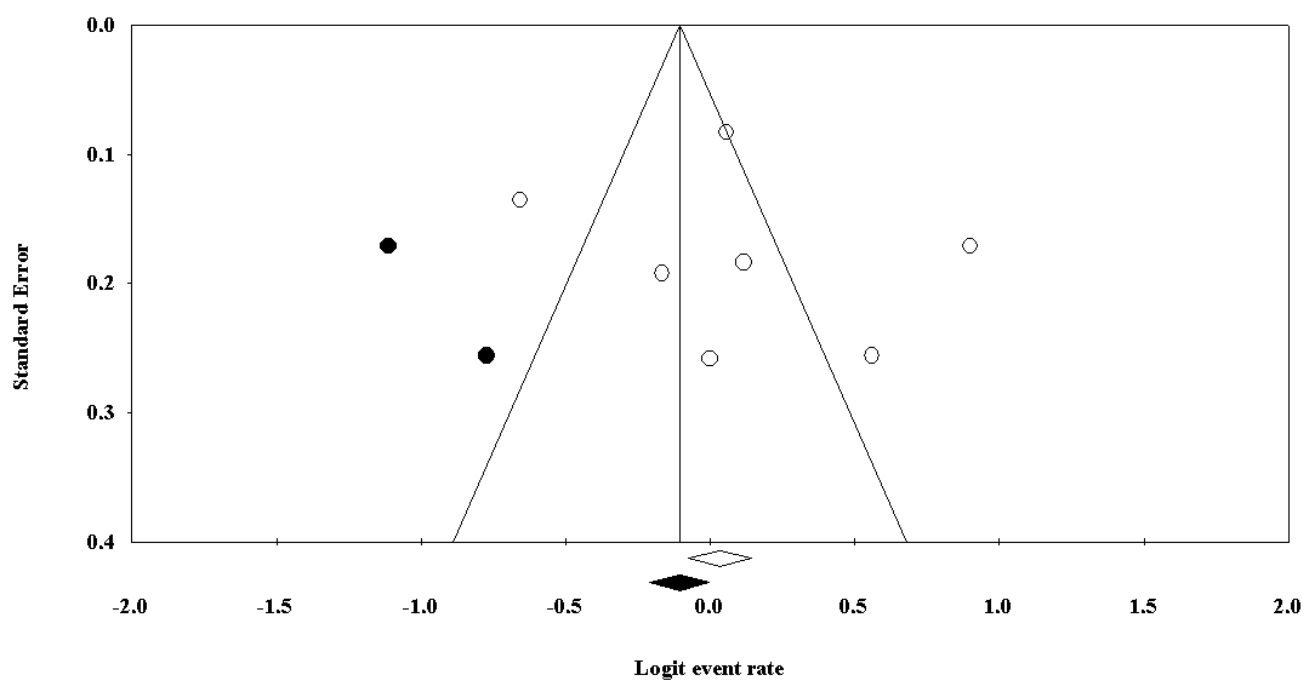

Figure 3. Funnel plot of studies investigating the knowledge of tooth fracture among physical education teachers.

At the meta-regression analysis, a non-statistically significant tendency for country was found $(\mathrm{Q}=7.55, p=0.056)$, with the lowest percentage of correct answers reported in studies conducted in India and with the highest percentage of correct answers reported in investigations carried out in Hong Kong.

No significant effects were detected for gender $(p=0.073$, although there were tendencies to an increasing rate of wrong answers in parallel with an increasing percentage of male participants), tool design $(p=0.628)$, question type $(p=0.720)$, study quality $(p=0.712)$, and sample size $(p=0.721)$. Interestingly, there was no effect of the number of years of teaching experience $(p=0.649)$.

A statistically significant effect of study year was found (meta-regression coefficient $=-0.05$ (95\% CI -0.08 to -0.02$)$, standard error $=0.02$, $\mathrm{z}$-value $=-2.87, p=0.004)$, as well as for validation (meta-regression coefficient $=-0.90(95 \% \mathrm{CI}-1.69$ to -0.10$)$, standard error $=0.41$, $\mathrm{z}$-value $=-2.21, p=0.027)$. For the other covariates, there were insufficient studies to perform the meta-regression analysis.

Pooling studies concerning the knowledge of tooth avulsion and its related management, $32.9 \%$ ( $(95 \%$ CI 23.7 to 43.5$\left.), \mathrm{I}^{2}=90.02 \%\right)$ gave a correct response concerning tooth avulsions (Figure 4$)$.

Newman and Crawford (1991)

Chan et al. (2001)

Holan et al (2006)

Subramaniam et al. (2011)

Panahi et al. (2014)

Bahandary and Shetty (2014)

D'Assunção et al. (2015)

Total (random effects)

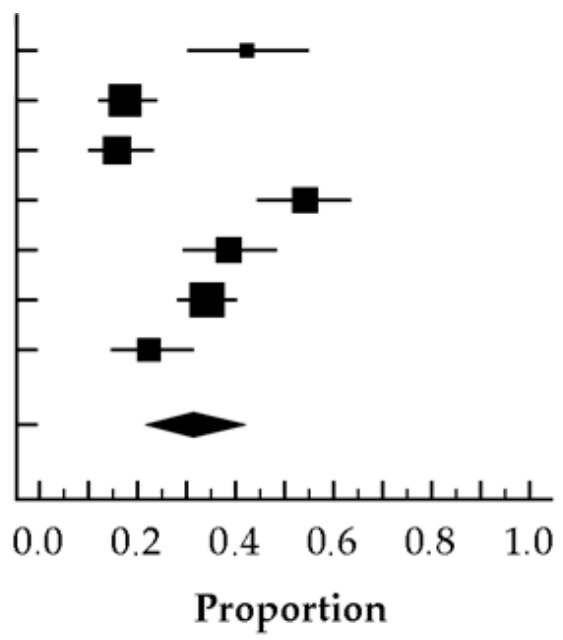

Figure 4. Forest plot of studies investigating the knowledge of tooth avulsion among physical education teachers. 
Visual inspection of the funnel plot and completion of a trim-and-fill analysis provided no evidence of publication bias.

At the meta-regression analysis, country had a significant effect on the outcome $(Q=11.24$, $p=0.047)$, with the lowest percentage rates of correct responses reported in Hong Kong and Israel (Figure 5).

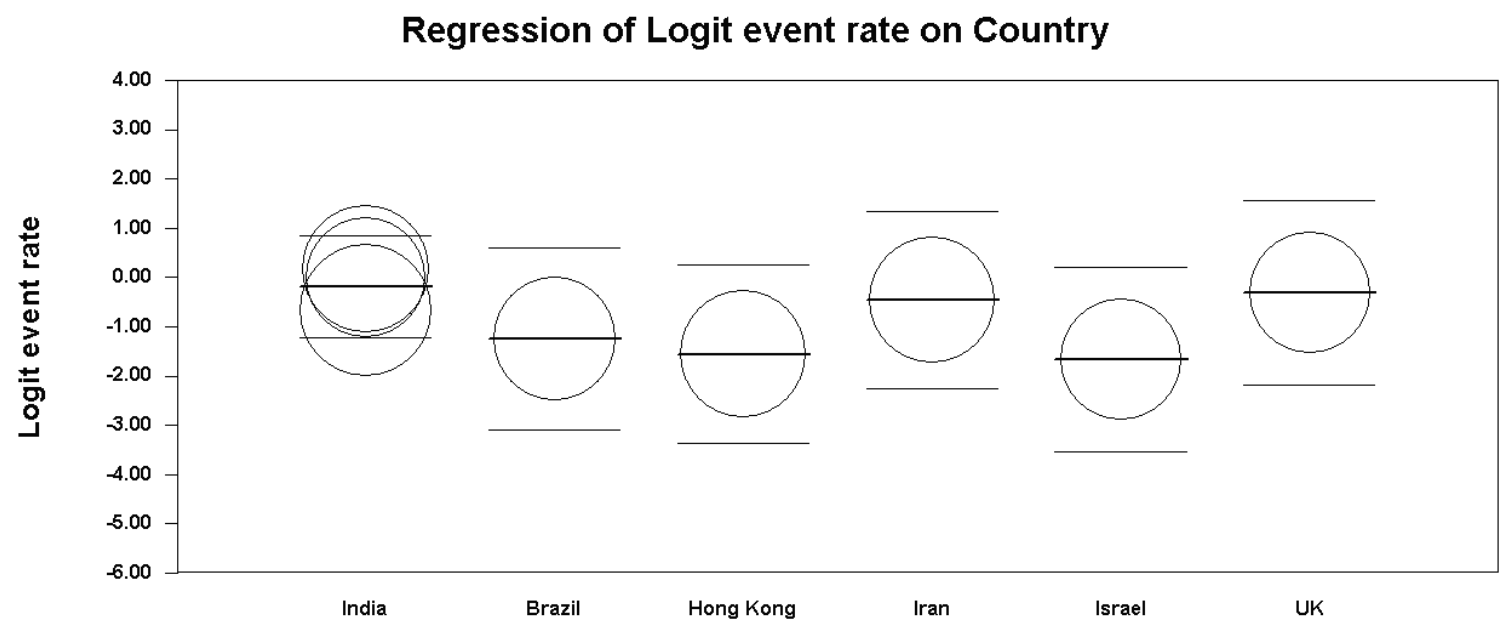

Figure 5. Meta-regression showing the effect of study country on the percentage of correct answers concerning the management of tooth avulsion among physical education teachers.

Gender (i.e., the percentage of male teachers) was another significant covariate (meta-regression coefficient $=0.03(95 \%$ CI 0.01 to 0.06$)$, standard error $=0.01$, z-value $=2.52, p=0.012$ ).

No significant effect of study year $(p=0.631)$, years of teaching experience $(p=0.331)$, tool design $(p=0.404)$, question type $(p=0.741)$, use of validated tools $(p=0.724)$, sample size $(p=0.287)$, or study quality $(p=0.754)$ could be found. For the other covariates, numbers were insufficient to perform meta-regression analyses.

Pooling the studies concerning tooth replantation, $16.5 \%$ ((95\% CI 11.1 to 23.9$), \mathrm{I}^{2}=90.04 \%$ ) gave a correct answer (Figure 6).

Holan et al. (2006)

Mohandas and Ghandan (2009)

Subramaniam et al. (2011)

Jorge et al. (2009)

Vergotine and Govoni (2010)

Pagliarin et al. (2011)

Lecor et al. (2013)

Bahandary and Shetty (2014)

Total (random effects)

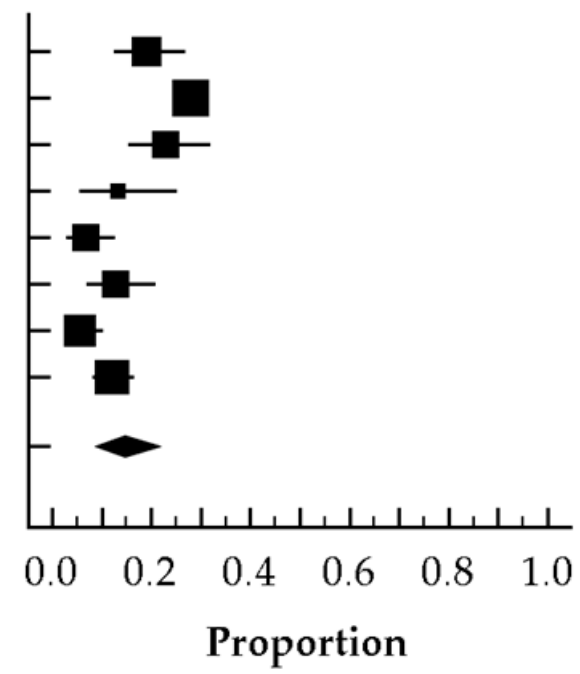

Figure 6. Forest plot of studies investigating the knowledge of replantation of avulsed tooth among physical education teachers.

Visual inspection of the funnel plot and the trim-and-fill analysis showed no evidence of publication bias. 
At the meta-regression analysis, country was an important covariate $(Q=45.53, p<0.001)$, with the highest percentage of correct responses related to tooth replantation procedure reported in India and the lowest percentage reported in Senegal and USA (Figure 7).

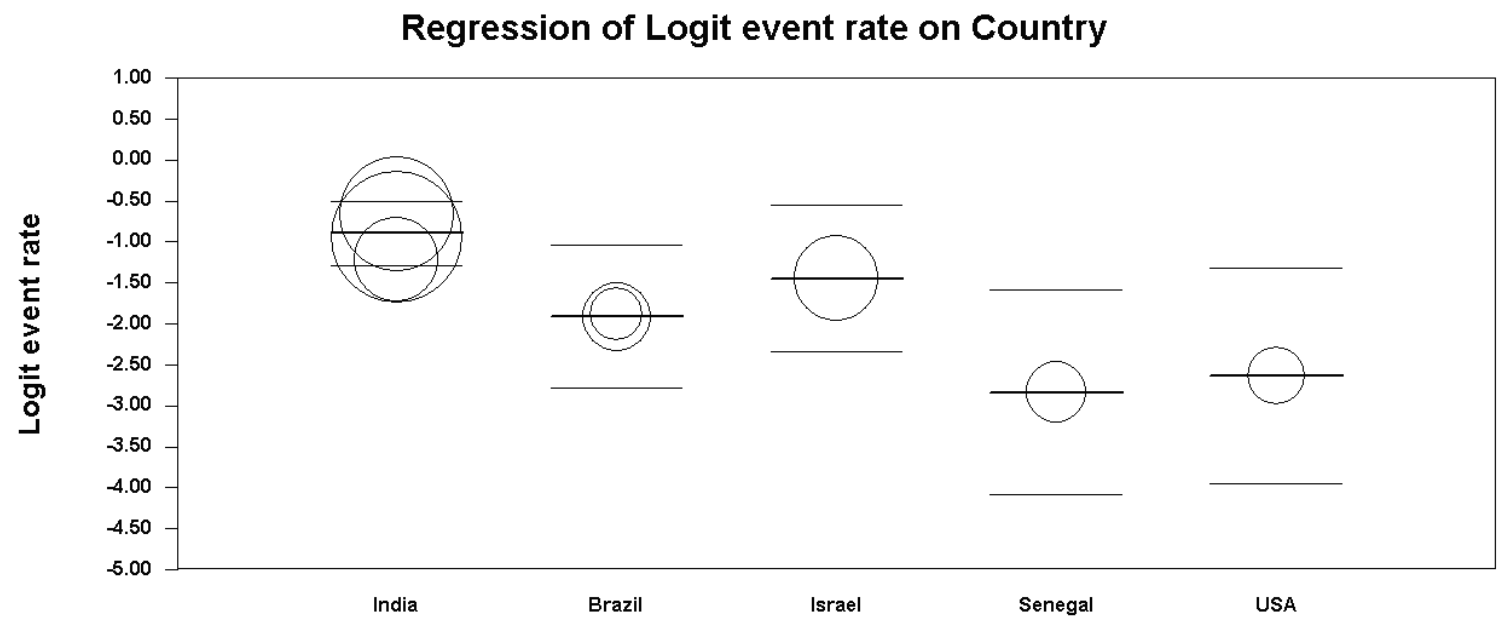

Figure 7. Meta-regression showing the effect of country on the knowledge of replantation of avulsed tooth among physical education teachers.

No effects could be detected for study year $(p=0.970)$, gender $(p=0.677)$, years of teaching experience $(p=0.151)$, tool design $(p=0.859)$, question type $(p=0.097)$, use of validated tools $(p=0.119)$, sample size $(p=0.179)$, or study quality $(p=0.295)$.

\subsection{Washing and Transporting Medium}

Mohandas and Ghandan [36] asked teachers about the best medium for transporting teeth; 124/580 (21\%) chose milk, 91/580 (16\%) chose water, and 338/580 (58\%) had no opinion. For Vergotine and Govoni [41], 27/119 (23\%) suggested milk, and for Chan et al. [38] 15/166 (9\%) selected milk. Surprisingly, $3 / 166(2 \%)$ would store the tooth in alcohol or an antiseptic solution [38]. An antiseptic solution was also chosen by 35/109 (32\%) teachers in the study of Subramaniam et al. [35]. Lecor et al. [39] found paper and compresses the most popular methods of conservation (56/162; 30\% each), with other suggestions being ice $(21 / 162 ; 13 \%)$, the child's mouth $(15 / 162 ; 9 \%)$, and saliva $(6 / 162 ; 4 \%)$. Only $16 / 162(10 \%)$ recommended liquid media, with running water as the most common recommendation, followed by antiseptic and iced water, and finally saline solution; surprisingly, no one proposed milk as the transportation medium [39]. Likewise, Jorge et al. [31] saw only 9/62 (14\%) of teachers suggesting milk, with 4/62 (6\%) proposing a dry medium [31]. Singh et al. [37] reported that 136/165 (82\%) of PE teachers answered correctly to the questions concerning the transportation media. For Holan et al. [43], a correct medium was identified by only 14/126 (11\%) of teachers. D’Assunção et al. [34] noted that saline solution was cited the most frequently $(58 / 103 ; 56 \%)$, while saliva $(3 / 103 ; 3 \%)$ was the least common recommendation. Anand et al. [44] found that 30/60 (50\%) most of the teachers would wash the area of an avulsed tooth; if the tooth was completely dislodged, 20/60 (33\%) of teachers would wash it under tap water, wrap it in a lean cloth, and carry it to the dentist. Prior to replantation, 8/109 (7\%) of the teachers responding to Subramaniam et al. [35] would scrub the tooth gently with a toothbrush prior to reimplantation and 15/109 (14\%) would rinse the tooth under tap water. Lecor et al. [39] commented that the most common proposed rinsing solution was running water $(71 / 162(44 \%))$, with 18/162 (11\%) recommending antiseptic solution, 16/162 (10\%) salt water, and 13/162 (8\%) toothpaste. In the sample of Panahi et al. [40], normal saline was chosen by 45/156 (29\%) and alcohol was chosen by 30/156 (19\%) of PE teachers. Bhandary and Shetty [42] found 129/243 (53\%) of teachers responding correctly that tap water was the best rinsing solution, and Granville-Garcia et al. [33] also reported that $64 / 79(81 \%)$ of the respondents would wash the tooth in running tap water. 
Pooling the studies concerning washing procedures of avulsed tooth, $47.7 \%$ ((95\% CI 35.7\% to $59.9 \%$ ), $\mathrm{I}^{2}=93.99 \%$ ) correctly indicated tap water (Figure 8 ).

By inspecting the funnel plot and at the trim-and-fill analysis, no publication bias was detected.

At the meta-regression analysis, a significant effect of country was found $(Q=10.20 p=0.017)$, with the lowest percentage of correct responses reported in India (Figure 9).

Granville-Garcia et al. (2007)

Mohandas and Ghandan (2009)

Subramaniam et al. (2011)

Lecor et al. (2013)

Bahandary and Shetty (2014)

Anand et al. (2016)

Total (random effects)

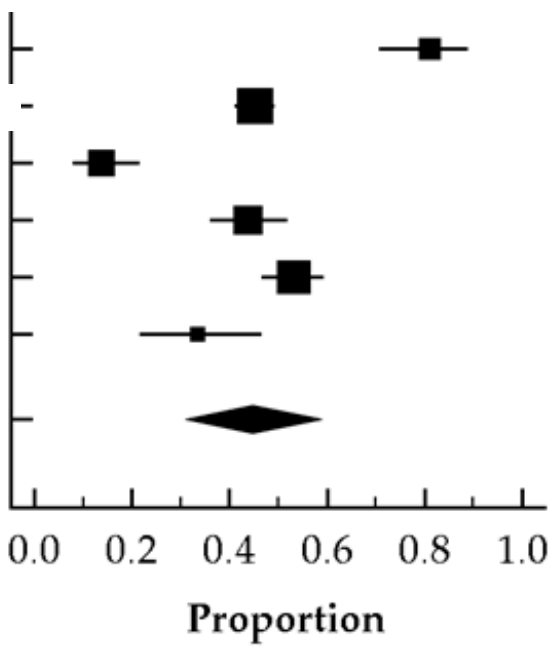

Figure 8. Forest plot of studies investigating the knowledge of the proper washing procedure of an avulsed tooth among physical education teachers.

\section{Regression of Logit event rate on Country}

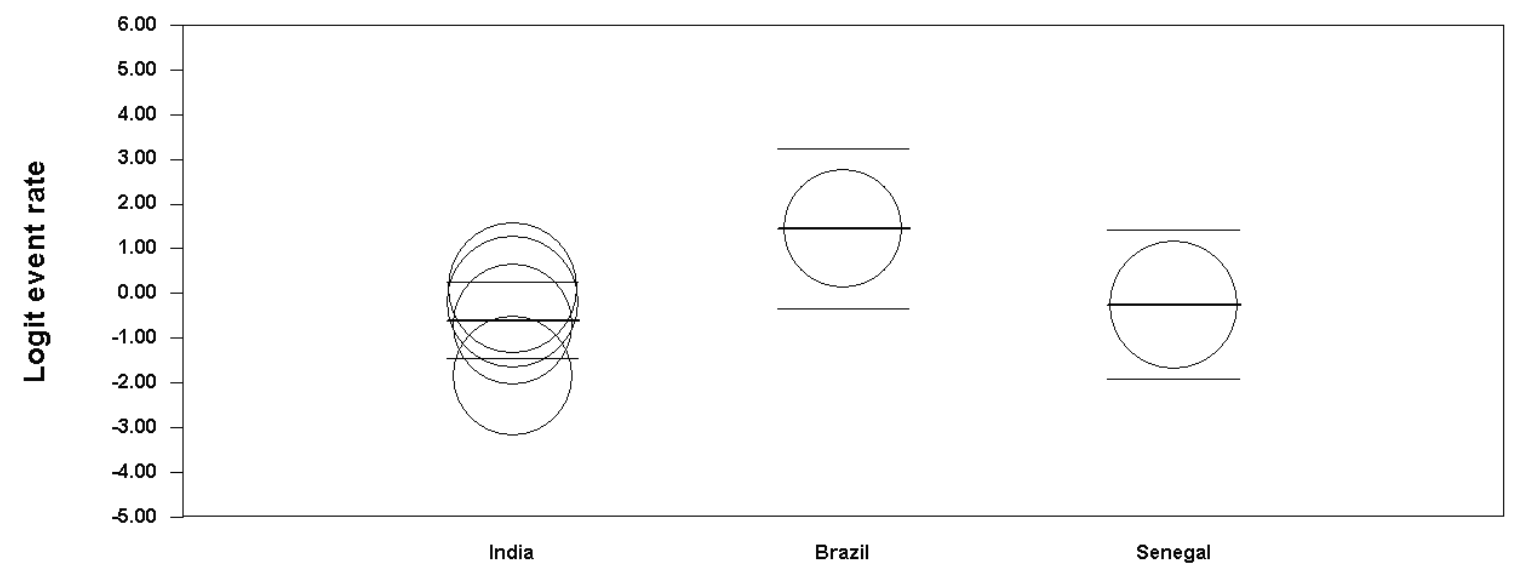

Figure 9. Meta-regression showing the effect of study country on the percentage rate of correct answers concerning the washing procedure of an avulsed tooth among physical education teachers.

Gender was another covariate achieving significance threshold at the meta-regression analysis (meta-regression coefficient $=-0.07$ (95\% CI 0.01 to 0.06 ), standard error $=0.03$, z-value $=-2.16, p=0.03$ ).

No significant effects of study year $(p=0.199)$, years of teaching experience $(p=0.211)$, question type $(p=0.889)$, tool design $(p=0.107)$, usage of validated tools $(p=0.450)$, sample size $(p=0.993)$, or study quality $(p=0.152)$ could be found.

Pooling studies concerning the proper transporting medium, $24.1 \%$ ((95\% CI $14 \%$ to $38.4 \%)$, $\mathrm{I}^{2}=96.74 \%$ ) indicated a correct response (Figure 10). 
Chan et al. (2001)

Holan et al. (2006)

Mohandas and Ghandan (2009)

Subramaniam et al. (2011)

Jorge et al. (2009)

Vergotine and Govoni (2010)

Lecor et al. (2013)

Singh et al. (2015)

D'Assunção et al. (2015)

Total (random effects)

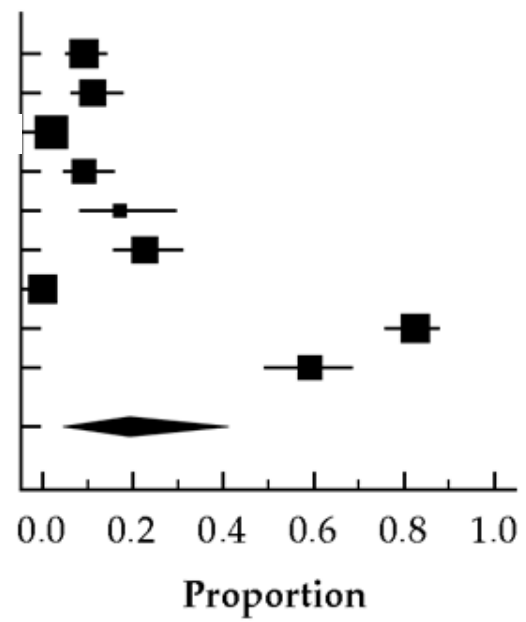

Figure 10. Forest plot of studies investigating the knowledge of the proper transporting medium of an avulsed tooth among physical education teachers.

No evidence of publication bias could be found.

At the meta-regression analysis, no effects of country $(p=0.543)$, sample size $(p=0.854)$ study year $(p=0.107)$, gender $(p=0.771)$, mean years of teaching $(p=0.877)$, tool design $(p=0.404)$, question type $(p=0.190)$, use of validated tools $(p=0.543)$, or study quality $(p=0.878)$ could be detected. It was not possible to conduct meta-regression analysis for the other covariates due to an insufficient number of studies.

\subsection{Extra-Alveolar Period of Avulsed Tooth}

For Jorge et al. [30], 31/53 (58\%) of teachers thought incorrectly that the ideal time for reimplantation was longer than $360 \mathrm{~min}$. In the sample of Subramaniam et al. [34], 3\% of teachers responded falsely that an extra-oral period of one day was acceptable. In the survey of Pagliarin et al. [31], 52/102 (51\%) of teachers did not know the answer, 24/102 (23\%) responded that $30 \mathrm{~min}$ was adequate, 14/102 (14\%) one hour, and 8/102 (8\%) up to two hours, while 4/102 (4\%) did not believe that extra-oral time was an important issue. When PE teachers were asked how urgently professional help was needed, 102/166 (61\%) felt it should be immediate [37] and a further 13/166 (8\%) within $30 \mathrm{~min}$; however, 43/166 (26\%) felt that "a few hours" was an acceptable upper limit and 7/166 (4\%) suggested that "one-day" extra-oral period was acceptable.

Pooling the studies concerning perceptions of an avulsed tooth as an emergency, $56.0 \%$ ((95\% CI 42.5 to 68.7$), \mathrm{I}^{2}=93.65 \%$ ) gave a correct response (Figure 11 ).

Chan et al. (2001)

Granville-Garcia et al. (2007)

Mohandas and Ghandan (2009)

Jorge et al. (2009)

Vergotine and Govoni (2010)

Lecor et al. (2013)

Total (random effects)

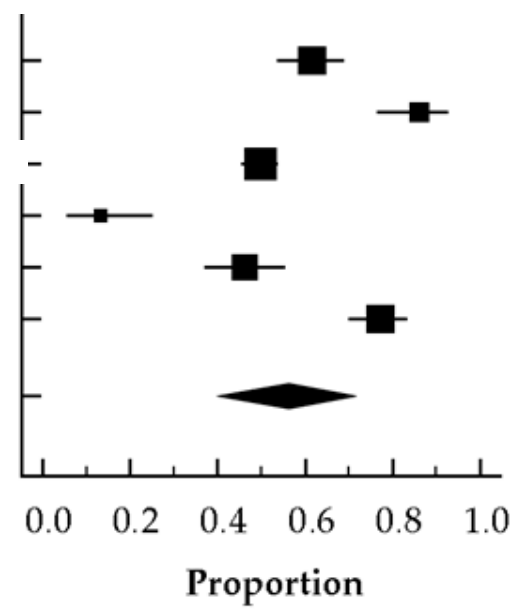

Figure 11. Forest plot of studies investigating the correct perception of tooth avulsion as an emergency among physical education teachers. 
No evidence of publication bias could be found.

At the meta-regression analysis, there was no significant effect of study year $(p=0.762)$, country $(p=0.916)$, gender $(p=0.918)$, years of teaching experience $(p=0.290)$, tool design $(p=0.076)$, question type $(p=0.476)$, sample size $(p=0.847)$, or study quality $(p=0.334)$. For the other predictors under study, there were too few investigations to perform a meta-regression analysis.

\subsection{Knowledge About the Effectiveness of Mouthguards}

Only two studies evaluated knowledge about the effectiveness of mouthguards [31,40]. Pagliarin et al. [31] reported that 71/102 (70\%) of respondents considered mouthguards as effective in preventing dental injuries, but the remainder did not. Similarly, Vergotine and Govoni [40] found 73\% of teachers indicating that mouthguards were mandatory for all contact sports in their school districts.

\subsection{Quality Assessment}

Scores ranged from 6 to 11 (mean score $=7.5$ ) out of a possible 14 (Table 3). Study flaws included non-representative or inadequately described samples, and many of the studies examined $(n=13)$ failed to report any validation of the questionnaires that they used.

Table 3. Quality ratings for selected studies.

\begin{tabular}{|c|c|c|c|c|c|c|c|c|c|c|c|c|c|c|c|}
\hline \multirow{2}{*}{ Reference } & \multicolumn{9}{|c|}{ Reporting } & \multicolumn{5}{|c|}{ Knowledge Tool Validity } & \multirow{2}{*}{$\begin{array}{c}\text { Total } \\
\text { Score/14 }\end{array}$} \\
\hline & 1 & 2 & 3 & 4 & 5 & 6 & 7 & 8 & 9 & 10 & 11 & 12 & 13 & 14 & \\
\hline [26] & 1 & 1 & 1 & 0 & 1 & 1 & 0 & 1 & NA & 0 & 0 & 0 & 0 & 0 & $6 / 13$ \\
\hline [37] & 1 & 1 & 1 & 1 & 1 & 1 & 0 & 1 & NA & 0 & 0 & 0 & 0 & 0 & $7 / 13$ \\
\hline [42] & 1 & 1 & 1 & 1 & 1 & 1 & 0 & 1 & 0 & 0 & 0 & 0 & 0 & 0 & $7 / 14$ \\
\hline [32] & 1 & 1 & 1 & 1 & 1 & 1 & 0 & 1 & NA & 1 & 0 & 0 & 0 & 0 & $8 / 13$ \\
\hline [35] & 1 & 1 & 1 & 1 & 1 & 1 & 1 & 1 & NA & 0 & 0 & 0 & 0 & 0 & $8 / 13$ \\
\hline [34] & 1 & 1 & 1 & 1 & 1 & 1 & 0 & 1 & NA & 0 & 0 & 0 & 0 & 0 & $7 / 13$ \\
\hline [30] & 1 & 1 & 1 & 0 & 1 & 1 & 1 & 1 & NA & 0 & 0 & 0 & 0 & 0 & $7 / 13$ \\
\hline [40] & 1 & 1 & 1 & 1 & 1 & 1 & 0 & 1 & NA & 0 & 0 & 0 & 0 & 0 & $7 / 13$ \\
\hline [31] & 1 & 1 & 1 & 1 & 1 & 1 & 0 & 1 & NA & 0 & 0 & 0 & 0 & 0 & $7 / 13$ \\
\hline [38] & 1 & 1 & 1 & 1 & 1 & 1 & 0 & 1 & NA & 0 & 0 & 0 & 0 & 0 & $7 / 13$ \\
\hline [39] & 1 & 1 & 1 & 1 & 0 & 1 & 1 & 1 & NA & 0 & 1 & 1 & 1 & 1 & $11 / 13$ \\
\hline [41] & 1 & 1 & 1 & 1 & 1 & 1 & 0 & 1 & NA & 0 & 0 & 0 & 0 & 0 & $7 / 13$ \\
\hline [36] & 1 & 1 & 1 & 1 & 1 & 1 & 0 & 1 & NA & 0 & 1 & 0 & 1 & 0 & $9 / 13$ \\
\hline [33] & 1 & 1 & 1 & 1 & 1 & 1 & 0 & 1 & NA & 0 & 0 & 0 & 0 & 0 & $7 / 13$ \\
\hline [43] & 1 & 1 & 1 & 0 & 1 & 1 & 0 & 1 & NA & 0 & 0 & 0 & 0 & 0 & $6 / 13$ \\
\hline
\end{tabular}

Abbreviations: NA (not applicable); item 1 (Hypothesis stated/aim stated); item 2 (Main outcomes); item 3 (Intervention described); item 4 (Participant description); item 5 (Main findings described); item 6 (Variability estimates); item 7 (Representative participants); item 8 (Appropriate statistical tests); item 9 (Adjust for confounders); item 10 (Face validity); item 11 (Pre-tested or pilot tested); item 12 (Content validity); item 13 (Test-retest); and item 14 (Internal consistency).

\section{Discussion}

The focus of this systematic review was on the level of knowledge and attitudes of PE teachers in the initial management of dental trauma and to provide some practical recommendations for improved immediate treatment. The studies reviewed broadly support the conclusion that most PE teachers lack adequate knowledge regarding first-aid measures for tooth fracture and avulsion. Moreover, although the majority of those questioned recognized the urgency of seeking professional assistance, they seemed unable to offer appropriate immediate first-aid management. However, the number of studies evaluating the knowledge of PE teachers on the effectiveness of mouthguard use remains limited, precluding any firm conclusions on this topic. Additionally, meta-regression results showed that the knowledge gap in the management of dental trauma is country specific. 


\subsection{Attitude Regarding Dental Injuries}

The majority of PE teachers recognized the urgency of seeking professional assistance following dental injury. However, few teachers considered themselves as able to perform an immediate reimplantation [30,33,42]. Reasons suggested by Holan et al. [42] included psychological deterrents, fear of legal implications, and avoidance of additional responsibilities. Jorge et al. [30] attributed inaction to a lack of appropriate knowledge, the presence of a professional from the field of dentistry, fear of injuring other structures, and not having the necessary instruments. Clearly, improving knowledge of dental first-aid should encourage teachers to take greater action in the immediate management of dental trauma.

\subsection{First-Aid Dental Trauma Knowledge}

Immediate reimplantation is the ideal treatment for avulsed teeth [19]. However, other procedures were proposed by PE teachers. Chan et al. [37], Granville-Garcia et al. [32], and Mohandes and Ghandan [35] all found that the first concern of the majority of respondents was stemming the bleeding; this may be a reflection of the basic teaching in first-aid programs [35,37]. Unfortunately, delay in reimplanting a tooth jeopardizes prognosis. Only $2 \%$ of Bangalore teachers said that they would look for the tooth and re-insert it [36]; this figure was much higher (17\%) in Hong Kong [37] possibly because the knowledge and training of teachers is greater in Hong Kong than in Bangalore. Correct handling of an avulsed tooth prior to reimplantation is also important $[18,44]$. It should be handled by the crown, not touching the root, and avoiding any contact with or possible damage to periodontal ligament cells. However, Pagliarin et al. [31] and D'Assunção et al. [33] found that a significant percentage of PE teachers did not know this and lacked knowledge about tooth ligaments. If a tooth cannot be reimplanted immediately, it should be stored in an appropriate liquid medium. Milk is considered a practical choice, easily available, and relatively free of bacteria [45,46]. Moreover, its osmolality is not excessively harmful to the periodontal ligament cells [46,47]. However, only a small percentage of the PE teachers questioned by Pagliarin et al. [31] recommended milk as the storage medium to transport the avulsed tooth; a significant percentage opted for tap water, which is undesirable because it provokes rapid cell lysis [47]. Surprisingly, a significant percentage of teachers suggested wrapping the tooth in paper tissue or a handkerchief [31-34,37]. Additionally, some respondents preferred ice or iced water $[34,37,38]$ probably because of the use of ice when transporting human organs and accidentally detached limbs $[34,37,38]$. An antiseptic solution was also chosen by a significant percentage of teachers [34,38,39], probably in an attempt to kill bacteria on the root surface [34,38]; unfortunately, they did not realize that this would also damage viable cells on the tooth $[34,38]$. An inappropriate washing procedure and an excessive extra-alveolar period of avulsed tooth were reported in most studies [31,34,38-40,43].

A large number of PE teachers responded incorrectly when asked about the first-aid management of tooth fracture $[26,39,40,43]$. Anand et al. [43] suggested there was a lack of both prior experience and information from other sources; further, in some situations PE teachers may be exposed to other traumatic events of greater severity, and, thus not consider a tooth fracture as an urgent priority [40].

\subsection{Practical Recommendations}

Given the current limitations of knowledge among PE teachers, it is important to give much greater emphasis to the prevention and management of dental trauma in the PE curriculum. The majority of $\mathrm{PE}$ teachers recognized that they needed further training to manage such cases appropriately [35,41]. Vergotine and Govoni [40] suggested that schools should consider making dental trauma education mandatory and/or mandate a recertification of PE teachers in this area on a regular basis.

Holan et al. [42] showed that PE teachers who attended a seminar including clear instructions on the appropriate treatment of avulsed permanent teeth increased their knowledge regarding the management of dental trauma compared with PE teachers who did not attend such a seminar. 
Al-Asfour et al. [48] evaluated the effectiveness of a 30-min informative lecture about tooth avulsion and replantation on the level of knowledge regarding the management of dental trauma in a sample of 43 teachers. The lecturer focused on the emergency treatment of avulsed permanent teeth and what should be performed by teachers in trauma situations before transferring the child with an avulsed tooth to a nearby dentist [48]. Additionally, the lecturer allowed time for discussion after the lecture and interactions between the lecturer and teachers were encouraged during the lecture [48]. The authors concluded that a lecture followed by discussion was an effective and efficient method of enhancing the knowledge level of teachers so that proper dental first-aid procedures could be achieved [48]. Al Sari et al. [49] also showed that an educational poster increased the knowledge of school nurses and PE teachers both immediately after the educational session and three months later. Clearly, an informative lecture, a seminar, or educational posters can be used to enhance the level of knowledge regarding the appropriate management of dental trauma.

Each school should prepare a dental first-aid box that includes an appropriate preservative medium. Further, education on the availability and types of mouthguard should be provided, and mouthguards should be distributed during lessons prone to cause dental injuries [50-56].

Given that we assessed inter-country differences in dental trauma first-aid knowledge, attitudes, and practices, policy- and decision-makers in individual countries can use information from the present article to be informed about specific gaps in national practices. In fact, specific attention should be paid to Indian PE teachers for the improvement of their knowledge related to the procedures of the washing of avulsed tooth. Furthermore, there is an urgent need to improve Senegalese and American PE teachers' knowledge of tooth replantation procedures.

It is worthy to note that the results of this meta-analysis with meta-regressions are preliminary in that in various cases meta-regression analyses assessing specific covariates could not be run due to insufficient studies included. As such, future research studies investigating the knowledge about dental trauma management in large cohorts of males and females and comparing between different countries are warranted.

\subsection{New Avenues for Research}

Based on the findings of the present systematic review and meta-analysis with meta-regressions, new psychometrically sound tools should be developed to screen PE knowledge and attitudes concerning the initial management of dental trauma, as well as to assess the effect of educational interventions (such as lectures, interactive forums, and seminars, or posters) aimed at making such knowledge more commonly available and practically effective. Longitudinal and randomized trials should be devised and performed with this objective.

\subsection{Strengths and Weaknesses}

This is the first systematic review and meta-analysis with meta-regressions evaluating the knowledge and attitudes of PE teachers concerning the initial management of dental trauma. Strengths of the study include a comprehensive coverage of the current literature, (having searched two scholarly databases, as recommended by the Cochrane Association guidelines and good practices for conducting systematic reviews), the absence of language restriction, and a careful appraisal of study quality.

However, results must be interpreted with caution, as methodological issues weakened most studies, including the use of various non-validated questionnaires, a lack of reported responses for some items, and high, statistically significant heterogeneity among studies.

Additionally, some of the comparisons between tool designs and between validation status are not easy to interpret; they are possibly confounded by other variables. 


\section{Conclusions}

This systematic review and meta-analysis with meta-regressions demonstrates that most PE teachers lack adequate knowledge on the initial management of dental trauma. Specific education is needed to encourage the greater use of mouthguards and to improve the emergency treatment of dental injuries during PE classes. Further rigorous studies on this issue are warranted, using validated questionnaires.

Author Contributions: Conceptualization, K.T., N.L.B. and H.C.; Data curation, K.T. and N.L.B.; Formal analysis, N.L.B.; Funding acquisition, N.L.B.; Investigation, K.T., N.L.B. and H.C.; Methodology, N.L.B.; Project administration, N.L.B.; Resources, N.L.B.; Software, N.L.B.; Supervision, K.T. and H.C.; Validation, K.T., N.L.B. and H.C.; Visualization, N.L.B.; Writing - original draft, K.T.; Writing - review \& editing, K.T., R.J.S., S.Z., O.B., A.A., A.K., S.K., N.L.B. and H.C.

Funding: This research received no external funding.

Conflicts of Interest: The authors declare no conflict of interest.

\section{References}

1. Janssen, I.; LeBlanc, A.G. Systematic review of the health benefits of physical activity and fitness in school-aged children and youth. Int. J. Behav. Nutr. Phys. Act. 2010, 7, 40. [CrossRef] [PubMed]

2. Biddle, S.J.; Asare, M. Physical activity and mental health in children and adolescents: A review of reviews. Br. J. Sports Med. 2011, 45, 886-895. [CrossRef] [PubMed]

3. Gomez-Pinilla, F. The combined effects of exercise and foods in preventing neurological and cognitive disorders. J. Prev. Med. 2011, 52, S75-S80. [CrossRef] [PubMed]

4. Lind, R.R.; Geertsen, S.S.; Ørntoft, C.; Madsen, M.; Larsen, M.N.; Dvorak, J.; Ritz, C.; Krustrup, P. Improved cognitive performance in preadolescent Danish children after the school-based physical activity programme "FIFA 11 for Health" for Europe-A cluster-randomised controlled trial. Eur. J. Sport Sci. 2018, 18, 130-139. [CrossRef] [PubMed]

5. Glendor, U. Epidemiology of traumatic dental injuries-A 12 year review of the literature. Dent. Traumatol. 2008, 24, 603-611. [CrossRef] [PubMed]

6. Yamaguchi-Ueda, K.; Kawarabayashi, K.; Miyazaki, A.; Kurogoushi, R.; Iwata, K.; Sugimoto, A.; Akazawa, Y.; Hasegawa, T.; Iwamoto, T. Prevention of sports-related dental Injuries in children. J. Oral Health Biosci. 2018, $31,68-72$.

7. García-Godoy, F.; Sánchez, R.; Sánchez, J.R. Traumatic dental injuries in a sample of Dominican schoolchildren. Community Dent. Oral Epidemiol. 1981, 9, 193-197. [CrossRef] [PubMed]

8. Bastone, E.B.; Freer, T.J.; McNamara, J.R. Epidemiology of dental trauma: A review of the literature. Aust. Dent. J. 2000, 45, 2-9. [CrossRef]

9. Gábris, K.; Tarján, I.; Rózsa, N. Dental trauma in children presenting for treatment at the Department of Dentistry for Children and Orthodontics, Budapest, 1985-1999. Dent. Traumatol. 2001, 17, 103-108. [CrossRef]

10. Sgan-Cohen, H.D.; Yassin, H.; Livny, A. Dental trauma among 5th and 6th grade Arab schoolchildren in Eastern Jerusalem. Dent. Traumatol. 2008, 24, 458-461. [CrossRef]

11. Al-Jundi, S.H.; Al-Waeili, H.; Khairalah, K. Knowledge and attitude of Jordanian school health teachers with regards to emergency management of dental trauma. Dent. Traumatol. 2005, 21, 183-187. [CrossRef] [PubMed]

12. Berger, T.D.; Kenny, D.J.; Casas, M.J.; Barrett, E.J.; Lawrence, H.P. Effects of severe dentoalveolar trauma on the quality of life of children and parents. Dent. Traumatol. 2009, 25, 462-469. [CrossRef] [PubMed]

13. Pujita, C.; Sivakumar Nuvvula, G.S.; Nirmala, S.V.S.G.; Yamini, V. Informative promotional outcome on school teachers' knowledge about emergency management of dental trauma. J. Conserv. Dent. 2013, 16, 21. [PubMed]

14. Emerich, K.; Nadolska-Gazda, E. Dental trauma, prevention and knowledge concerning dental first-aid among Polish amateur boxers. J. Sci. Med. Sport 2013, 16, 297-301. [CrossRef] 
15. Andreasen, J.O.; Andreasen, F.M.; Skeie, A.; Hjørting-Hansen, E.; Schwartz, O. Effect of treatment delay upon pulp and periodontal healing of traumatic dental injuries-a review article. Dent. Traumatol. 2002, 18, 116-128. [CrossRef]

16. Andreasen, J.O.; Andreasen, F.M.; Andersson, L. Textbook and Color Atlas of Traumatic Injuries to the Teeth; Wiley-Blackwell: Oxford, UK, 2018.

17. Frujeri, M.E.; Costa, E.D. Effect of a single dental health education on the management of permanent avulsed teeth by different groups of professionals. Dent. Traumatol. 2009, 25, 262-271. [CrossRef]

18. Flores, M.T.; Andersson, L.; Andreasen, J.O.; Bakland, L.K.; Malmgren, B.; Barnett, F.; Bourguignon, C.; DiAngelis, A.; Hicks, L.; Sigurdsson, A.; et al. Guidelines for the management of traumatic dental injuries. II. Avulsion of permanent teeth. Dent. Traumatol. 2007, 23, 130-136. [CrossRef]

19. Emerich, K.; Kaczmarek, J. First aid for dental trauma caused by sports activities. Sports Med. 2010, 40, 361-366. [CrossRef]

20. Levin, L.; Zadik, Y. Education on and prevention of dental trauma: it's time to act! Dent. Traumatol. 2012, 28, 49-54. [CrossRef]

21. Andersson, L.; Andreasen, J.O.; Day, P.; Heithersay, G.; Trope, M.; DiAngelis, A.J.; Kenny, D.J.; Sigurdsson, A.; Bourguignon, C.; Flores, M.T.; et al. International Association of Dental Traumatology guidelines for the management of traumatic dental injuries: 2. Avulsion of permanent teeth. Dent. Traumatol. 2012, 28, 88-96. [CrossRef]

22. Andersson, L.; Andreasen, J.O.; Day, P.; Heithersay, G.; Trope, M.; DiAngelis, A.J.; Kenny, D.J.; Sigurdsson, A.; Bourguignon, C.; Flores, M.T.; et al. Guidelines for the management of traumatic dental Injuries: 2. Avulsion of Permanent Teeth. Pediatr. Dent. 2018, 39, 412-419.

23. Andreasen, J.O.; Andreasen, F.M. Essentials of Traumatic Injuries to the Teeth: A Step-by-Step Treatment Guide; John Wiley \& Sons: New York, NY, USA, 2010.

24. Roettger, M.; Greaves, M.; Ahmad, M.; Leon-Salazaar, V. Sports-Related Oral and Dentoalveolar Trauma: Pathophysiology, Diagnosis, and Emergent Care. In Modern Sports Dentistry; Springer: Champaign, IL, USA, 2018; pp. 23-55.

25. Nirwan, M.; Syed, A.A.; Chaturvedi, S.; Goenka, P.; Sharma, S. Awareness in primary school teachers regarding traumatic dental injuries in children and their emergency management: A survey in south Jaipur. Int. J. Clin. Pediatr. Dent. 2016, 9, 62. [PubMed]

26. Newman, L.J.; Crawford, P.J. Dental injuries: "first aid" knowledge of Southampton teachers of physical education. Dent. Traumatol. 1991, 7, 255-258. [CrossRef]

27. Moher, D.; Liberati, A.; Tetzlaff, J.; Altman, D.G. Preferred reporting items for systematic reviews and meta-analyses: The PRISMA statement. Ann. Intern. Med. 2009, 151, 264-269. [CrossRef] [PubMed]

28. Downs, S.H.; Black, N. The feasibility of creating a checklist for the assessment of the methodological quality both of randomised and non-randomised studies of health care interventions. J. Epidemiol. Community Health 1998, 52, 377-384. [CrossRef] [PubMed]

29. Duval, S.; Tweedie, R. Trim and fill: A simple funnel-plot-based method of testing and adjusting for publication bias in meta-analysis. Biometrics 2000, 56, 455-463. [CrossRef]

30. Jorge, K.O.; Moysés, S.J.; Ferreira, E.F.; Ramos-Jorge, M.L.; de Araújo Zarzar, P.M.P. Prevalence and factors associated to dental trauma in infants 1-3 years of age. Dent. Traumatol. 2009, 25, 185-189. [CrossRef]

31. Pagliarin, C.L.; Zenkner, C.L.; Barletta, F.B. Knowledge of physical education teachers about emergency management of tooth avulsion. Stomatos 2011, 17, 33-42.

32. Granville-Garcia, A.F.; Lima, E.M.; Gomes Santos, P.; De Menezes, V.A. Avaliação do conhecimento dos professores de educação física de Caruaru-PE sobre avulsão-reimplante. Pesqui. Bras. Odontopediatria Clin. Integr. 2007, 7. [CrossRef]

33. D'Assunção, F.L.C.; de Melo, Â.B.P.; Salazar-Silva, J.R.; de Oliveira Lima, J.; Fernandes, L.C.C.; de Melo, N.F.P. Knowledge level of physical educators regarding dental trauma in a Brazilian subpopulation. Pesqui. Bras. Odontopediatria Clin. Integr. 2015, 15, 441-449.

34. Subramaniam, R.; Mittal, S.; Hiregoudar, M.; Mohandas, U.; Sakeenabi, B.; Prashant, G.M.; Chandu, G.N. Knowledge of upper primary and secondary school physical education instructors in Davangere city, India, about emergency management of dental trauma. J. Educ. Ethics Dent. 2011, 1, 18. 
35. Mohandas, U.; Chandan, G.D. Knowledge, attitude and practice in emergency management of dental injury among physical education teachers: A survey in Bangalore urban schools. J. Indian Soc. Pedod. Prev. Dent. 2009, 27, 242. [PubMed]

36. Singh, M.; Ingle, N.A.; Kaur, N.; Yadav, P. Evaluation of knowledge and attitude of school teachers about emergency management of traumatic dental injury. J. Int. Soc. Prev. Community Dent. 2015, 5, 108. [CrossRef] [PubMed]

37. Chan, A.W.; Wong, T.K.; Cheung, G.S. Lay knowledge of physical education teachers about the emergency management of dental trauma in Hong Kong. Dent. Traumatol. 2001, 17, 77-85. [CrossRef]

38. Lecor, P.A.; Niang, P.D.A.; Diouf, M.; Sarr, M.; Diop, E.C.; Sall, O.H.; Touré, B. Connaissances et attitudes des enseignants d'éducation physique et sportive (EPS) sur la prise en charge de l'expulsion de l'incisive centrale maxillaire. J. Traumatol. Sport 2013, 30, 220-224. [CrossRef]

39. Panahi, J.; Havasian, M.R.; Roozegar, M.A. Knowledge of physical education teachers' toward tooth avulsion in Tehran, Iran. J. Oral Health Oral Epidemiol. 2014, 3, 66-71.

40. Vergotine, R.J.; Govoni, R. Public school educator's knowledge of initial management of dental trauma. Dent. Traumatol. 2010, 26, 133-136. [CrossRef]

41. Bhandary, S.; Shetty, S. Emergency management of dental trauma among physical education teachers of 2 districts in Karnataka, India. Asian J. Sports Med. 2014, 5, 139-140.

42. Holan, G.; Cohenca, N.; Brin, I.; Sgan-Cohen, H. An oral health promotion program for the prevention of complications following avulsion: The effect on knowledge of physical education teachers. Dent. Traumatol. 2006, 22, 323-327. [CrossRef]

43. Anand, A.; Mukherjee, C.G.; Shukla, J.N.; Sharma, S. Knowledge and Awareness Regarding Traumatic Dental Injuries in School Children among Physical Education Teachers in Patna: A Cross-Sectional Study. Int. J. Sci. Study 2016, 4, 51-54.

44. Andersson, L.; Bodin, I. Avulsed human teeth replanted within $15 \mathrm{~min}$ : A long-term clinical follow-up study. Endod. Dent. Traumatol. 1990, 6, 37-42. [CrossRef] [PubMed]

45. Blomlöf, L.; Otteskog, P.; Hammarström, L. Effect of storage in media with different ion strengths and osmolalities on human periodontal ligament cells. Eur. J. Oral Sci. 1981, 89, 180-187. [CrossRef] [PubMed]

46. Nordenvall, K.J. Milk as storage medium for exarticulated teeth: Report of case. ASDC J. Dent. Child. 1992, 59, 150-155. [PubMed]

47. Trope, M. Clinical management of the avulsed tooth: Present strategies and future directions. Dent. Traumatol. 2002, 18, 1-11. [CrossRef]

48. Al-Asfour, A.; Andersson, L.; Al-Jame, Q. School teachers' knowledge of tooth avulsion and dental first aid before and after receiving information about avulsed teeth and replantation. Dent. Traumatol. 2008, 24, 43-49. [CrossRef]

49. Al Sari, S.; Kowash, M.; Hussein, I.; Al-Halabi, M. An educational initiative for Dubai school nurses and physical education teachers on the management of traumatic dental injuries. J. Sch. Nurs 2018, in press. [CrossRef]

50. Raphael, S.L.; Gregory, P.J. Parental awareness of the emergency management of avulsed teeth in children. Aust. Dent. J. 1990, 35, 130-133. [CrossRef]

51. Stokes, A.N.; Anderson, H.K.; Cowan, T.M. Lay and professional knowledge of methods for emergency management of avulsed teeth. Dent. Traumatol. 1992, 8, 160-162. [CrossRef]

52. Costa, A.B.M. Traumatismos Alvéolo-Dentários: Avaliação dos Conhecimento e Atitudes de uma Amostra de Professores do Ensino Fundamental do Município de São Paulo; 135f. Dissertação (Mestrado); Faculdade de Odontologia, Universidade de São Paulo: São Paulo, Brazil, 2002.

53. Pacheco, L.F.; Filho, P.F.G.; Letra, A.; Menezes, R.; Villoria, G.E.M.; Ferreira, S.M. Evaluation of the knowledge of the treatment of avulsions in elementary school teachers in Rio de Janeiro, Brazil. Dent. Traumatol. 2003, 19, 76-78. [CrossRef]

54. Panzarini, S.R.; Pedrini, D.; Brandini, D.A.; Poi, W.R.; Santos, M.F.; Correa, J.P.T.; Silva, F.F. Physical education undergraduates and dental trauma knowledge. Dent. Traumatol. 2005, 21, 324-328. [CrossRef] 
55. Mori, G.G.; Turcio, K.H.L.; Borro, V.P.B.; Mariusso, Â.M. Evaluation of the knowledge of tooth avulsion of professionals from Adamantina, São Paulo, Brazil. Dent. Traumatol. 2007, 23, 2-5. [CrossRef] [PubMed]

56. Randhawa, A.K.; Kaur, K.; Walia, S.S.; Kaur, G. Mangement of traumatic dental injuries in school children: A questionnaire survey on the school teachers to assess their knowledge regarding the same. IJCDC 2015, 5, 514-517.

(c)

(C) 2019 by the authors. Licensee MDPI, Basel, Switzerland. This article is an open access article distributed under the terms and conditions of the Creative Commons Attribution (CC BY) license (http://creativecommons.org/licenses/by/4.0/). 